\title{
Power-Efficient Hybrid Energy Storage System for Seismic Nodes
}

\author{
Dauda Duncan $\left(\mathbb{D},{ }^{1}\right.$ Adamu Murtala Zungeru $\mathbb{D}^{1},{ }^{1}$ Mmoloki Mangwala $\left(\mathbb{D},{ }^{1}\right.$ \\ Bakary Diarra $\mathbb{D}^{2},{ }^{2}$ Bokani Mtengi $\mathbb{D}^{1},{ }^{1}$ Thabo Semong $\mathbb{D D}^{3}$ and Joseph M. Chuma $\mathbb{D}^{1}$ \\ ${ }^{1}$ Department of Electrical, Computer and Telecommunications Engineering, \\ Botswana International University of Science and Technology, Private Bag 16, Palapye, Botswana \\ ${ }^{2}$ Department of Electrical Engineering, Institute of Applied Sciences, \\ University of Sciences, Techniques and Technologies of Bamako (USTTB), Bamako, Mali \\ ${ }^{3}$ Department of Computer Science and Information Systems, Botswana International University of Science and Technology, \\ Private Bag 16, Palapye, Botswana
}

Correspondence should be addressed to Adamu Murtala Zungeru; zungerum@biust.ac.bw

Received 11 July 2020; Revised 14 September 2020; Accepted 23 October 2020; Published 12 November 2020

Academic Editor: Chuan-Yu Wu

Copyright (c) 2020 Dauda Duncan et al. This is an open access article distributed under the Creative Commons Attribution License, which permits unrestricted use, distribution, and reproduction in any medium, provided the original work is properly cited.

Recent surveys in the energy harvesting system for seismic nodes show that, most often, a single energy source energizes the seismic system and fails most frequently. The major concern is the limited lifecycle of battery and high routine cost. Simplicity and inexperience have caused intermittent undersizing or oversizing of the system. Optimizing solar cell constraints is required. The hybridization of the lead-acid battery and supercapacitor enables the stress on the battery to lessen and increases the lifetime. An artificial neural network model is implemented to resolve the rapid input variations across the photovoltaic module. The best performance was attained at the epoch of 117 and the mean square error of $1.1176 \mathrm{e}-6$ with regression values of training, test, and validation at $0.99647,0.99724$, and 0.99534 , respectively. The paper presents simulations of Nsukka seismic node as a case study and to deepen the understanding of the system. The significant contributions of the study are (1) identification of the considerations of the PV system at a typical remote seismic node through energy transducer and storage modelling, (2) optimal sizing of PV module and lead-acid battery, and, lastly, (3) hybridization of the energy storage systems (the battery and supercapacitor) to enable the energy harvesting system to maximize the available ambient irradiance. The results show the neural network model delivered efficient power with duty cycles across the converter and relatively less complexities, while the supercapacitor complemented the lead-acid battery and delivered an overall efficiency of about $75 \%$.

\section{Introduction}

The acquired seismic data from their nodes are analyzed and demonstrated to produce a seismic hazard map for mitigation measures before the effects of future earthquakes. They are utilized in the design of dams, bridges, and civil engineering structures [1]. The success of a seismic node relatively resides in a steady and continuous source of electrical power, whether standalone or networked. With the growing concern in developing near-real-time seismicity of areas, continuous and long-term seismic data acquisition is a prerequisite. Most frequently, the energy harvesting system at conventional remote seismic nodes is by means of a photovoltaic module and lead-acid batteries, which mostly fail [2]. In the case study, hardly 1 out of the 7 remote seismic nodes in the network does exhaust its battery effectively in a single year without fail. This causes gaps in the seismic database or faulty seismometers. The survey shows naive and inexperience in the sizing and configuration of its energy storage. A functional seismic node consists of a seismometer, seismic recorder, Global Positioning System (GPS) unit, and network interface, as shown in Figure 1. The node senses Earth vibrations, acquires the data continuously, and never goes to sleep. The seismometers are categorized based on sensing local, regional, or global Earth movements. The seismic recorder is an embedded system which processes data and controls and coordinates the activities of the node, and it runs on Linux or Windows operating system. The GPS 


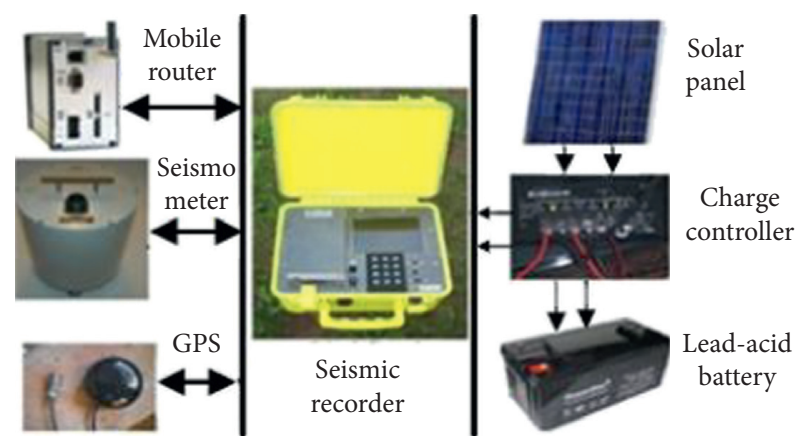

FIGURE 1: The layout of energy harvesting system powering Nsukka seismic node.

introduces the timing signals into the data, while the network interface provides the telemetry. Each subsystem requires a reliable, steady, and continuous power supply to enhance seismic node processes and their network configurations $[3,4]$. An unstable power supply generates ripples along with the vertical component of a broadband seismometer [5]. In a case study carried out in [6], the unstable power supply led to unpredictable sensor performance, and this resulted in erroneous observations that can be avoided by the continuous and steady power supply.

The continuous and constant operation of the node prompts the lead-acid battery to deplete. Meanwhile, geoscientists need continuous and long-term seismic data to study the subsurfaces on a near real-time basis. The photovoltaic (PV) system is the most friendly and frequently used energy harvesting solution at remote nodes. However, it exhibits relatively low efficiency due to the irregularity of its input parameters such as ambient irradiance and temperature levels as well as nonlinearity characteristics of its elements. The lead-acid battery is the secondary energy source, and as soon as it is depleted, the remote seismic node is shutdown or malfunctions, causing discontinuities in the seismic database.

It is expected of all remote seismic nodes to be located in the quietest remote area where there are no human activities. Replacing the battery frequently affects the continuity of the seismic database and the integrity of the data and deters the real-time analysis of the subsurface. Integration of a leadacid battery and supercapacitor can assist in lessening the stress and increasing the lifecycle of the battery [7]. An artificial neural network is proposed in this study to predict optimal duty cycles across the DC-DC converter. The classical maximum power tracking methods such as Perturb and Observe algorithm determine optimal duty cycles slowly and generate oscillations across the load. The study presents the theoretical studies of the subsystems of the PV system and the lead-acid battery as well as the neural network algorithm.

The layout of an energy harvesting system powering Nsukka seismic node is shown in Figure 1, which comprises PV module and lead-acid battery as the only sources of energy without any form of optimization. The DC-DC converter employed lacks the Maximum Power Point Tracking (MPPT) system and characterized by low efficiency. The converter takes a lot of life from a conventional battery. Broadband seismometers are active electronic feedback sensors that require reliable, steady, and continuous power to function optimally [3]. An erratic lifecycle and limited power or energy density of energy storage hinder the possibility of lasting acquisition of seismic data, resulting in an inaccurate seismic analysis [8].

The target of this study is to develop a neural network algorithm to train the historical ambient irradiance and temperature measurements of a seismic node to predict the duty cycles across the DC-DC converter. The historical data are acquired by Perturb and Observe algorithm using Powersim (PSIM) simulating tool. The lead-acid battery will be integrated with the supercapacitor to enhance the operations of seismic instrumentation.

The contributions of this study can be summarized as follows:

(i) Identification of the considerations of the PV system at a typical remote seismic node through energy transducer and storage modelling

(ii) Optimal sizing of PV module and lead-acid battery

(iii) Hybridization of the battery and supercapacitor to enable the energy harvesting system to maximize the available ambient irradiance

The remainder of the paper is organized as follows. Section 2 discusses related works on implementing efficient energy harvesting systems. Section 3 investigates materials and methods, their backgrounds, and modelling of the study, including the presentation of a case study at a remote seismic node. In Section 4, we present the results and discussions. And Section 5 concludes the paper.

\section{Related Works}

Several approaches to energize remote nodes by energy harvesting systems have been reported in the literature. However, each remote node requires different considerations of energy transducers, energy storage, energy conversion, and the required constraints are optimized. A reliable and sustainable energy harvesting system requires logical optimization at all stages of design and implementation $[9,10]$. Authors [11-14] applied the design of PV module, battery, buck/boost converter, PWM, and MPPT as functional subsystems for various efficiencies and optimization, which led to increased output current resulting in expensive and complex subsystems. The author in [15] pointed out that annexing ambient energy is not the only necessary process in energy harvesting, but energy storage is also critical. The untimely depletion battery adversely affects remote nodes, even at practical installations [16]. Thus, a supercapacitor, which has a longer lifecycle and is more efficient than a battery, should be considered when implementing a solar energy harvesting system at remote nodes.

To track maximum power from the PV system, conventional MPPT algorithms such as Perturb and Observe, are mostly used [17-19], to manage non-uniform inputs and non-linearity of its cells [20-22]. These are undesirable 
considerations and often supply inappropriate duty cycles across the DC-DC converter and oscillates at the point of tracking the maximum power. The lead-acid battery is the usual energy storage deployed at the remote seismic node, which frequently gets depleted and unable to deliver throughout the seasons. A supercapacitor connected parallel with the battery across a passive DC-DC converter will enable more energy to be stored and results in an increased life cycle of the battery. Combined supercapacitor and leadacid battery techniques provide optimal and relatively cheap energy storage for the load $[23,24]$. Neural network algorithm has a fast response to nonuniform inputs of a PV system. It deals with nonlinearity of a system and tracks maximum optimal power across the PV system [25-31].

The study in $[15,15]$ indicated that the supercapacitor has a high power density and poor energy density. The hybrid energy storage of supercapacitor and battery delivers reliability and extends the lifecycle. The study in [32] avoided the use of MPPT by merely connecting the photovoltaic directly to the battery, and the linear mode regulator was employed. It caused power wastage due to mismatch and, ultimately, low efficiency. The study in [33] used supercapacitor and battery as hybrid energy storage, charged by a solar energy harvesting source for remote sensor nodes. Although the charging circuit prevented the reduction of the lifecycle of the battery and increased efficiency, the circuit was naive, and the duty cycle was traded off with the lifecycle of energy storage. This will cause inappropriate duty cycles for the DC-DC converter and loss of power. The node requires a continuous and cost-effective power supply.

Solar energy harvesting has a high energy density, and, hence, it is considered a good energy source for remote seismic nodes. However, due to the intermittencies of inputs across the PV module, efficient energy storage is incorporated. The energy storage, as in the case of a seismic node, is a lead-acid battery, charged by the PV module to provide energy when the module falls short. A lead-acid battery is fairly sustainable for seismic deployment at a remote site because they are usually not funded adequately $[34,35]$. In the PV system, the battery could be connected in parallel with the supercapacitor and then to a passive DC-DC converter to make more power available for the seismic instrumentation. The hybrid of lead-acid battery and supercapacitor enhances the lifecycle and performance [36-38].

According to the literature cited, optimization of energy harvesting systems was performed for only one subsystem, either the energy transducer, energy storage, or DC-DC converter. While the approaches enhanced the subsystems, due to their complexity, they fail regularly. These are not universal solutions for low power electronics like remote seismic nodes. Moreover, the loads across the PV system are not for operations such as remote seismic node where little funding, long-term, and sustainability are put into consideration. The case study at Nsukka seismic node is not different from the rest of the other seismic nodes in Africa. The neural network algorithm on the Matlab program simply trains historical data acquired by Perturb and Observe algorithm on the PSIM program and predicts duty cycles across the converter.

\section{Materials and Methods}

3.1. Energy Transducer and Storage Modelling. Modelling is the primary tool of a practical system. It enables the influence of different considerations of the system to be revealed. The energy transducer of an energy harvesting system is a subsystem that harvests ambient energy and recharges the energy storage connected to it. In this study, the PV transducer is the energy transducer, and it converts the ambient irradiance levels to electrical energy. The energy storage is a critical subsystem in an energy harvesting system, and integrating two or more different energy storage techniques leads to a combination of their advantages and improves the overall performance. While designing an energy harvesting system, models of the subsystems are required to represent equivalent circuits derived from analytical equations. These models should be able to simulate correctly with the variations of their parameters.

3.1.1. Energy Transducer Modelling. The solar cell is a typical PV transducer, produced from a semiconductor diode. When irradiance levels are inclined on it, electrical energy levels are generated. In this study, the single-diode equivalent circuit model is employed and taken as the reference model. An ideal solar cell equivalent circuit consists of a current source connected in parallel with a forward-biased $p-n$ junction and a shunt resistance, $R_{\mathrm{sh}}$, all in series with resistance $R_{s}$, as shown in Figure 2. Ambient irradiance and temperature levels influence these parameters and their outputs.

A Matlab simulation plot shown in Figure 3 is obtained from the solar cell model under irradiance and temperature variations. The photovoltaic module is characterized by its inherent parameters $R_{\mathrm{sh}}, R_{s}, I_{\mathrm{pv}}$, and $I_{D}$ as shown in Figure 2, as well as external parameters, ambient irradiance, and temperature levels. The modelling of the PV module is based on (2):

$$
\begin{aligned}
& I_{L}=I_{\mathrm{PV}}-I_{D}-I_{\mathrm{sh}}, \\
& I_{L}=I_{\mathrm{PV}}-I_{\mathrm{sat}}\left\{\exp \left[\frac{q\left(V_{\mathrm{oc}}+I_{L} R_{s}\right)}{\mathrm{KTA}}\right]-1\right\}-\frac{V_{\mathrm{oc}}+I_{L} R_{s}}{R_{\mathrm{sh}}} .
\end{aligned}
$$

3.1.2. Ambient Irradiance Consideration. Ambient irradiance is a key consideration of energy conversion in PV systems. It is the amount of light energy that strikes on a square meter per second. It is a promising source of energy due to the huge amount of energy available daily. The plots in Figures 4 and 5 represent the typical behaviors of the solar cell. Along the plots are the maximum power points to deliver optimal outputs.

The figures were observed to generate increased current and power output when the values of the irradiance were increased.

3.1.3. Ambient Temperature Consideration. An increase in ambient temperature levels adversely affects the parameters 


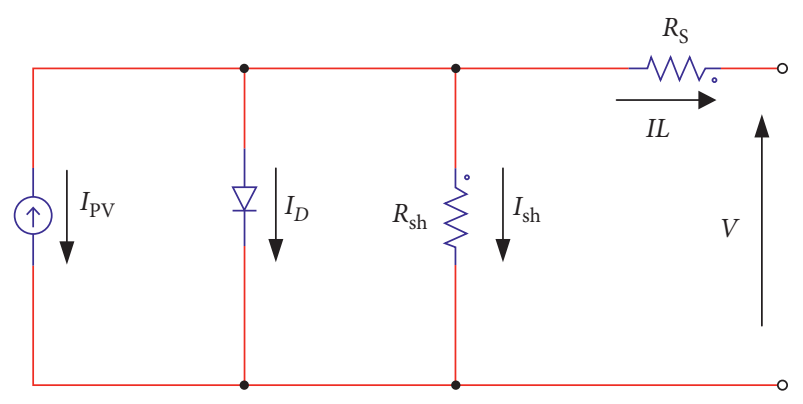

FIgURE 2: Equivalent solar cell circuit.

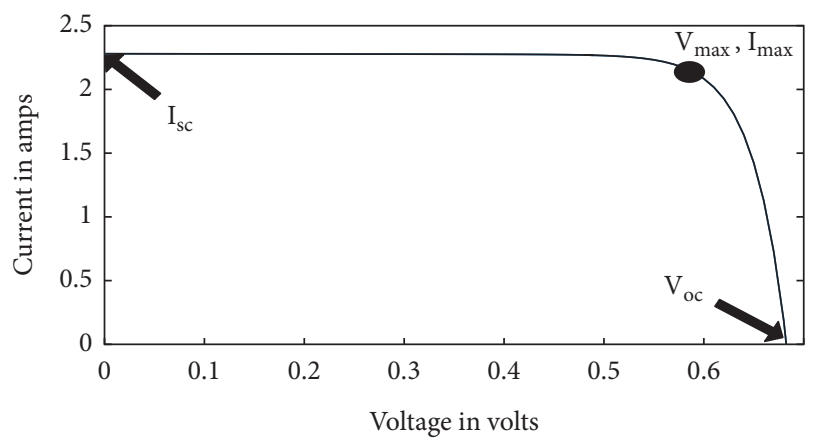

FIgURE 3: Simulated result of a solar cell.

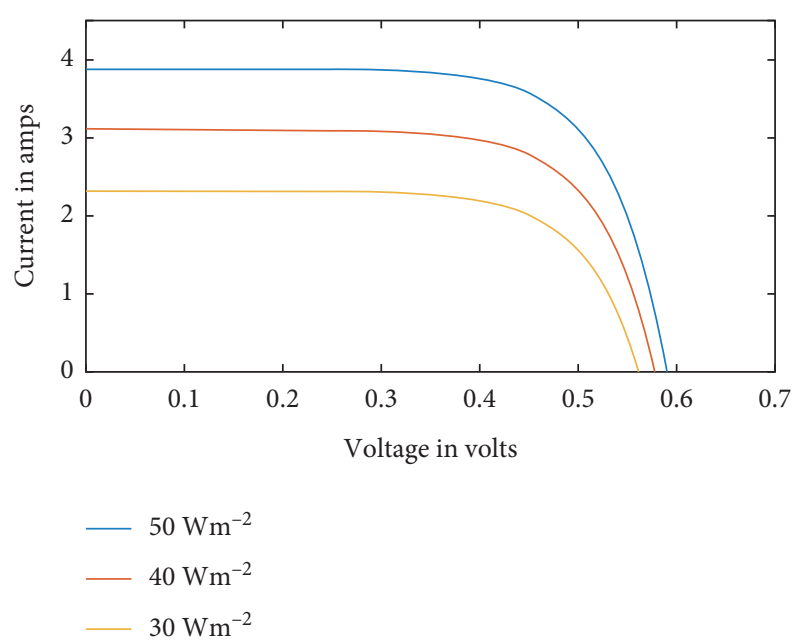

FIGURE 4: Simulated I-V plot of varying Irradiance of a solar cell.

of solar cells [39]. The inherent nonlinear parameters of the solar cell strongly depend on the operating temperature [39] as expressed in (2) and influence the saturation current of the diode in the cell. Figures 6 and 7 exhibit increased temperature levels and lowered voltage outputs. In comparison, the increased irradiance levels increased the current and power outputs.

3.1.4. Series and Shunt Resistances Considerations. The resistances of series and shunt elements in a solar cell circuit are shown in Figure 2. There are parasitic losses, which affect the relationships among current, voltage, and power

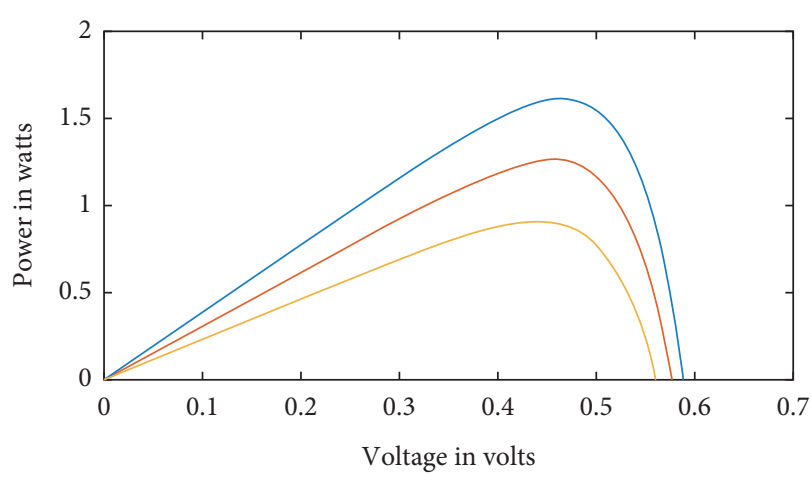

$-50 \mathrm{Wm}^{-2}$

$-40 \mathrm{Wm}^{-2}$

$-30 \mathrm{Wm}^{-2}$

FIGURE 5: Simulated P-V plot of varying Irradiance of a solar cell.

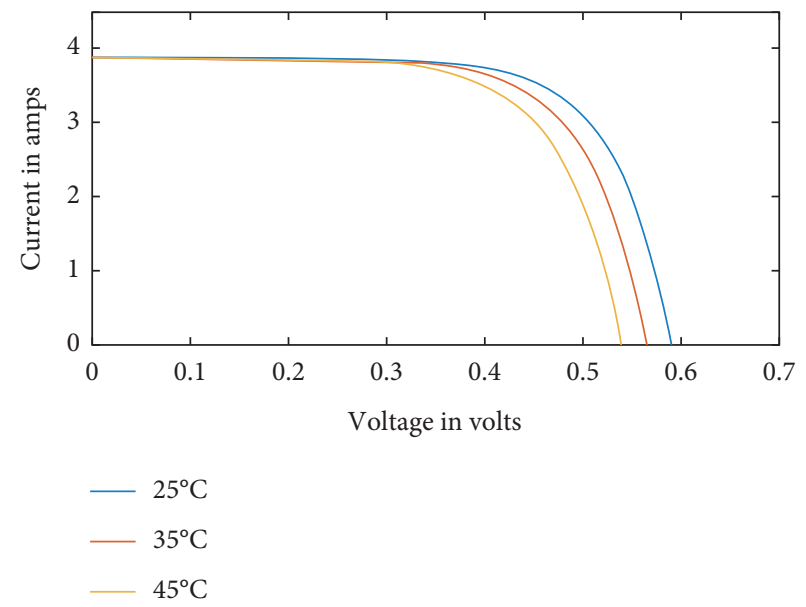

FIGURE 6: Simulated I-V plot of varying temperature of a solar cell.

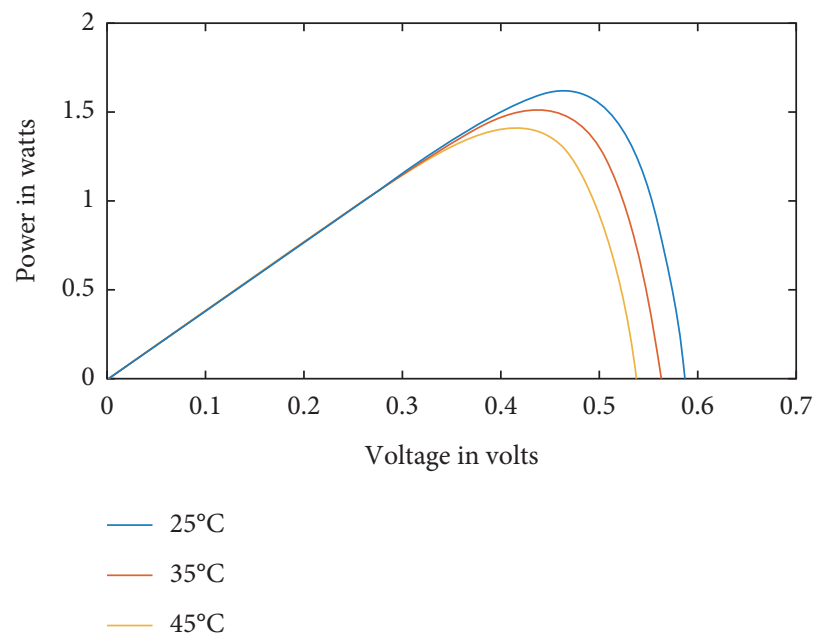

Figure 7: Simulated P-V plot of varying temperature of a solar cell. 


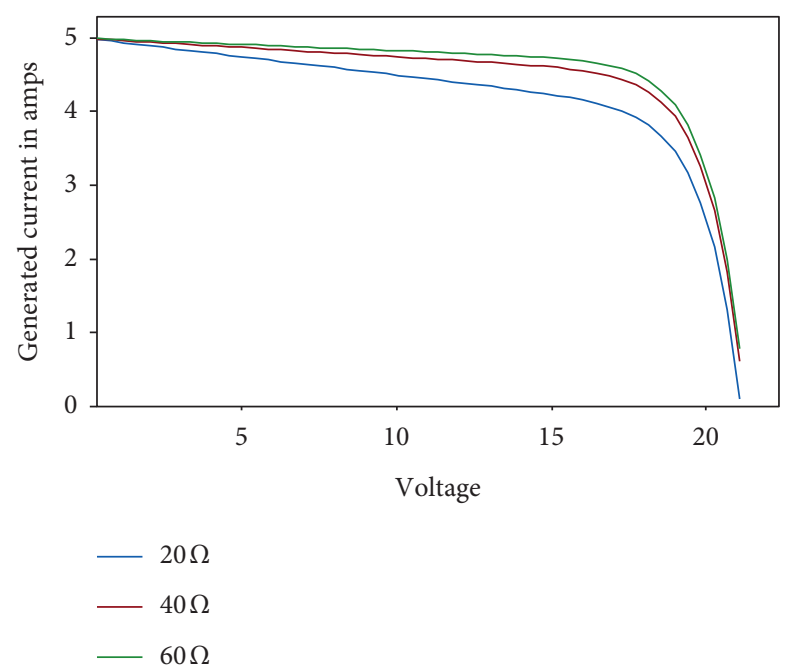

FIgURE 8: Simulated I-V plot of varying $R_{\mathrm{sh}}$ of solar cell.

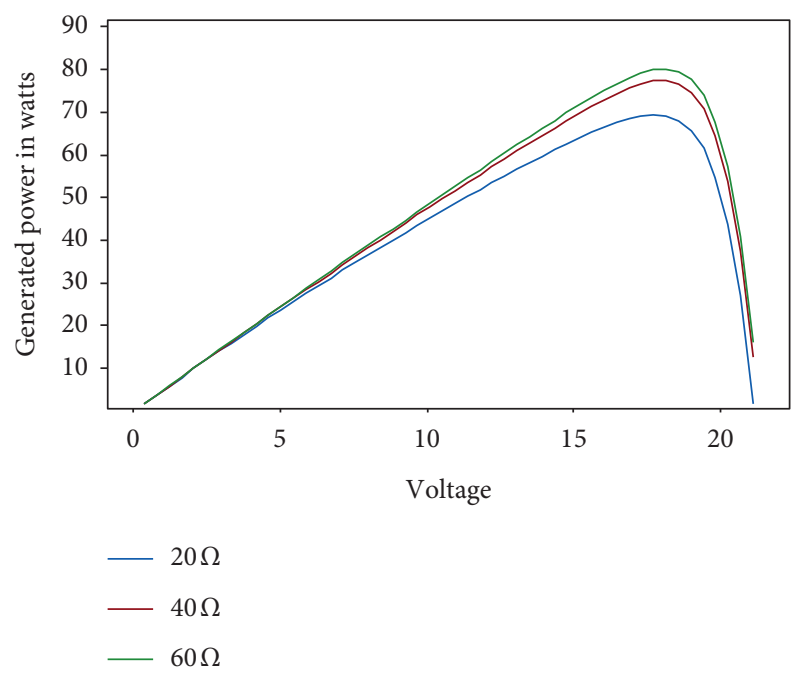

FIgURE 9: Simulated P-V plot of varying $R_{\mathrm{sh}}$ solar cell.

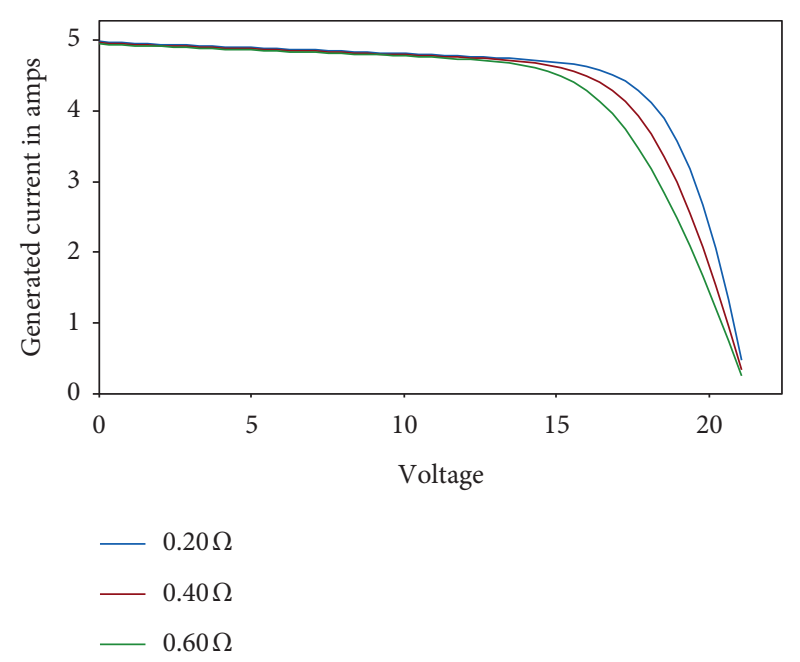

FIgURE 10: Simulated I-V plot of varying $R_{s}$ of solar cell.

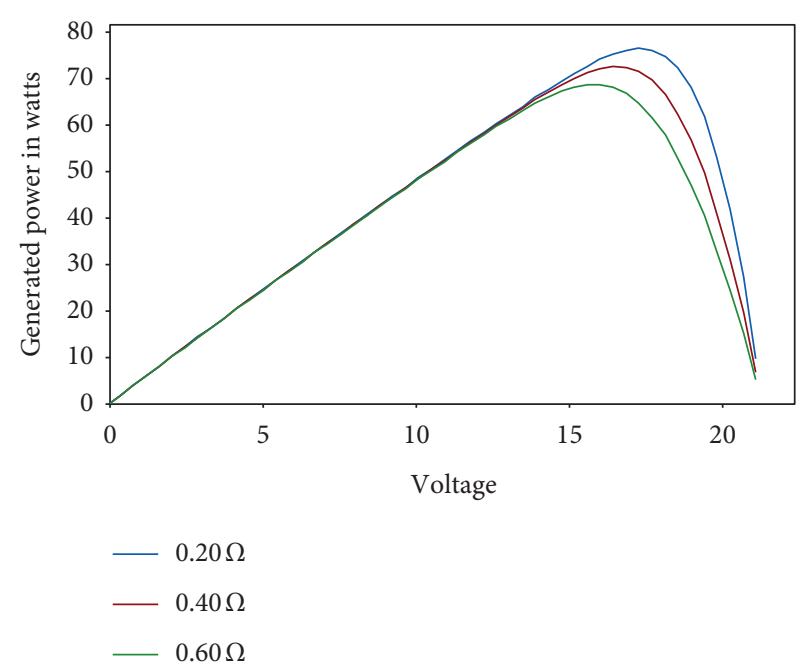

FIGURE 11: Simulated P-V plot of varying $R_{s}$ solar cell.

levels, as well as the efficiency of the cell. The photovoltaic model is efficiently designed when its shunt and series resistance are optimally selected because they are characterized by power losses [40, 41], as shown in Figures $8-11$. The photocurrent, Ipv produced by a solar cell can be expressed by (3) [42] as

$$
\begin{aligned}
& I_{\mathrm{PV}}=\left[I_{\mathrm{sc}}+\left(k_{i} *\left(T-T_{\mathrm{ref}}\right)\right)\right] * \frac{G}{G_{\mathrm{ref}}}, \\
& I_{\mathrm{sh}}=\frac{V_{\mathrm{oc}}+\left(I_{L} * R_{s}\right)}{R_{\mathrm{sh}}} \\
& I_{\mathrm{sat}}=I_{\mathrm{rs}}\left(\frac{T}{T_{\mathrm{ref}}}\right)^{3} \exp \left[\frac{q * E_{g^{0}}}{A * K}\left(\frac{1}{T}-\frac{1}{T_{\mathrm{ref}}}\right)\right], \\
& I_{\mathrm{rs}}=I_{\mathrm{sc}} \exp \left[\left(\frac{q * V_{\mathrm{oc}}}{(A * K * T)}\right)-1\right]
\end{aligned}
$$

where $I_{\mathrm{rs}}$ is reverse saturation current of the cell.

Generated power, $P=\mathrm{IV}$, where

$$
P=V\left\{I_{\mathrm{PV}}-I_{\mathrm{sat}}\left[\exp \left(\frac{q\left(V_{\mathrm{oc}}+I R_{s}\right)}{\mathrm{KTA}}\right)-1\right]-\frac{V_{\mathrm{oc}}+I R_{s}}{R_{\mathrm{sh}}}\right\} .
$$

Fixed $R_{s}$ and varying $R_{\mathrm{sh}}$ are shown in Figures 8 and 9. An increase in $R_{\mathrm{sh}}$ led to higher current as well as power. While in Figures 10 and 11, when $R_{s}$ is varied and with constant $R_{\mathrm{sh}}$, increased in $R_{s}$, the output current and power levels decreased, but the VOC remained unchanged. Neglecting $R_{\mathrm{sh}}$ and $R_{S}$ values leads to a change in the current, voltage, and power relationships, as shown in Figures 8-11, and the key factor is in obtaining the maximum power points. The variations in the curves arose due to power losses from the resistances [43]. This shows the practical behaviors of $R_{\mathrm{sh}}$ and $R_{\mathrm{s}}$ against the PV module. 
3.2. Lead-Acid Battery and Supercapacitor Modelling. In seismic deployment, where long-term continuous and low funding are taken into consideration, optimal selecting of the size, cost, and lifecycle of energy storage are required. No single energy storage can meet all the requirements of a sensitive sensor node like a seismic node [44], and the leadacid battery is not an exception. The lead-acid battery is easy to install, fairly cheap, and reliable. The lead-acid battery has a limited lifespan compared to the supercapacitor, which is a better option due to its longer lifespan. The two considerations of a lead-acid battery are Voc and the state of charge (SOC). They determine the state of charge and percentage of battery at the time of charging, respectively. Figures 12 and $13[45,46]$ show a simple lead-acid battery and supercapacitor topology that are appropriate for our application, respectively.

Integrating the battery and the supercapacitor, as shown in Figure 14, without losing their efficiencies, can relatively deal with the lifespan, charge, and discharge rate challenges at the node. The combination of the lead-acid battery and the supercapacitor is to slow down the depletion of the battery energy and optimally utilize the much-wasted energy when the battery is fully charged [45].

3.3. Case Study at a Remote Seismic Node. In this section, observations at a remote seismic node, located in southeast Nigeria, Nsukka seismic node 06052.022 N, 07025.045 E, were taken. This is to deepen the understanding of the considerations of the energy harvesting system at a remote seismic node. The data of irradiance, temperature, and battery voltage were acquired and analyzed using original energy harvesting system parameters. The photovoltaic power supply has four $60 \mathrm{~W}$ PV modules, a lead-acid battery $12 \mathrm{~V}, 200 \mathrm{Ah}$, and a DC-DC regulation without optimization. Tables 1 and 2 are populated with the electrical specifications at the seismic node, and Figure 15 shows the topology of the Nsukka seismic node.

The simulations of the energy harvesting system were done using a Matlab program. The plots of ambient irradiance and temperature measurements at the Nsukka seismic node are presented in Figures 16 and 17, respectively. The measurements were obtained from a weather station operated by Centre for Atmospheric Research, Anyigba, Nigeria.

3.3.1. Determination of the Subsystems and the Considerations. In this study, subsystems $I_{\mathrm{PV}}, I_{\mathrm{rs}}, I_{\text {sat }}$, and $I_{\text {sh }}$ were considered and varied based on their input parameters, while ambient irradiance and temperature levels were considered as the external parameters. The final outputs are current, $I_{L}$, and the voltage across the load. Table 3 shows how the variations of the parameters affect the subsystems. Case study parameters were used to determine the outputs using Simulink.

3.3.2. Photocurrent, $I_{P V}$, as a Consideration. Photocurrent values depend on solar cells ambient irradiance $(G)$ and temperature $(T)$ levels, which are key considerations in cell

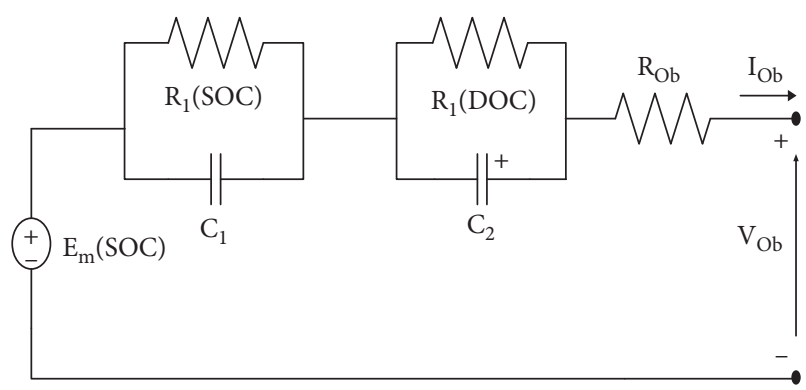

Figure 12: Simple lead-acid battery topology.

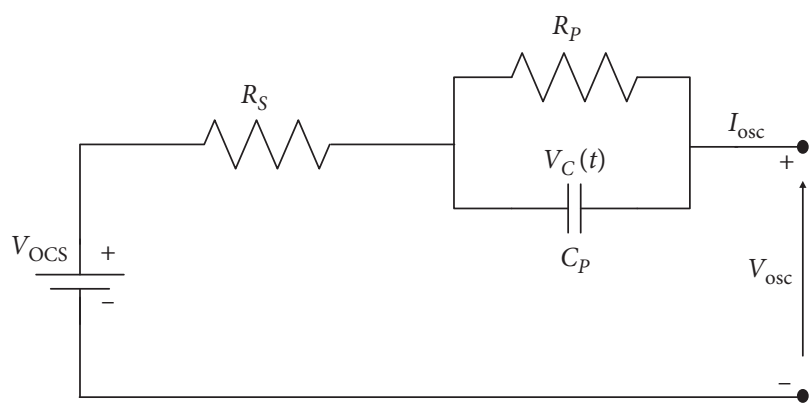

FIGURE 13: Simple supercapacitor topology.

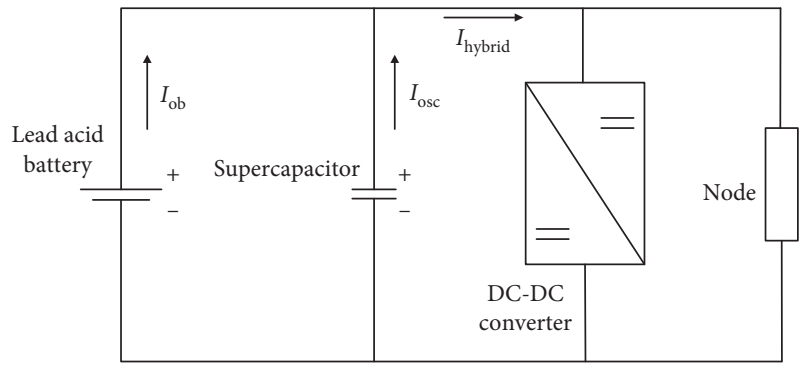

Figure 14: Hybrid of lead-acid battery and supercapacitor.

modelling. It is computed using (8) [47]. Based on (3), the short-circuit current, Isc, is provided by the vendor in the module datasheet and modelled as shown in Figure 18:

$$
I_{\mathrm{PV}}(G, T)=\frac{G}{G_{\mathrm{ref}}}\left(I_{\mathrm{SC}}+K_{i} d T\right)
$$

3.3.3. Reverse Saturation Current, $I_{r s}$, as a Consideration. The reverse saturation current, $I_{\mathrm{rs}}$ subsystem, relies on the ambient temperature input $T$, as shown in Figure 19. Its variations, which directly affect both $I_{\mathrm{sc}}$ and $I_{\text {sat }}$, are presented in Table 4, based on (5) and (6). They are mostly negligible but worth monitoring to avoid adverse reactions and power losses.

3.3.4. Saturation Current, $I_{\text {sat }}$, as a Consideration. The saturation current, $I_{\text {sat }}$, is a function of the ambient temperature as shown in the simulation model of Figure 20. $I_{\text {sat }}$ 
TABLE 1: Summary of notations and definitions.

\begin{tabular}{lc}
\hline Notation & Definition \\
\hline$I_{\mathrm{PV}}$ & Photocurrent generated from irradiance incident on the solar cell \\
$I_{D}$ & Diode current \\
$I_{\mathrm{sh}}$ & Current flowing through parallel resistance \\
$I_{L}$ & Load current \\
$R_{s}$ & Parasitic series resistance \\
$R_{\mathrm{sh}}$ & Parallel shunt resistance \\
$V_{\mathrm{OC}}$ & Open circuit voltage \\
$I_{\mathrm{sc}}$ & Short circuit current \\
$I_{\mathrm{sat}}$ & Saturation current of the diode \\
$T$ & Operating temperature \\
$T_{\mathrm{ref}}$ & Reference temperature \\
$G$ & Ambient irradiance \\
$G_{\mathrm{ref}}$ & Reference irradiance \\
$q$ & Charge of an electron \\
$K$ & Boltzmann's constant \\
$A$ & Ideality constant of the diode \\
$E_{g 0}$ & Band gap energy of the semiconductor \\
\hline
\end{tabular}

Table 2: Summary of notations and definitions.

\begin{tabular}{lc}
\hline Notation & Definition \\
\hline$E_{m}$ & Open circuit voltage of the lead-acid battery \\
$R_{1}$ & Resistance of the first elemental circuit of RC branch \\
$R_{2}$ & Resistance of the second elemental circuit of RC branch \\
$C_{1}$ & Capacitance of the first elemental circuit of RC branch \\
$C_{2}$ & Capacitance of the second elemental circuit of RC \\
$R_{\mathrm{Ob}}$ & branch \\
$R_{S}$ & Internal resistance of the lead-acid battery \\
$R_{P}$ & Internal equivalent series resistance \\
$I_{\mathrm{ob}}$ & Internal equivalent parallel resistance \\
$I_{\mathrm{OSC}}$ & Lead-acid battery output current \\
$V_{\mathrm{Ob}}$ & Supercapacitor output current \\
$V_{\mathrm{OCS}}$ & Lead-acid battery output voltage \\
$I_{\text {hybrid }}$ & Open circuit voltage of the supercapacitor \\
\hline
\end{tabular}

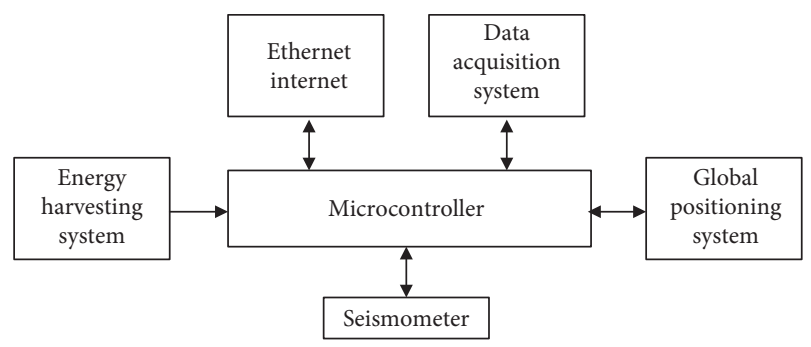

FIgURE 15: A topology of a functional seismic node.

flows due to reverse saturation through the diode, and it varies inversely with output current $I_{L}$ as demonstrated earlier in Table 4.

3.3.5. Shunt Current, $I_{s h}$, as a Consideration. Shunt current flows through the resistance, $R_{\mathrm{sh}}$, as shown in Figure 21. The simulation model of Figure 21 and (1) explained how the load current, $I_{L}$, is obtained by subtracting the shunt and diode current from $I_{\mathrm{PV}}$.

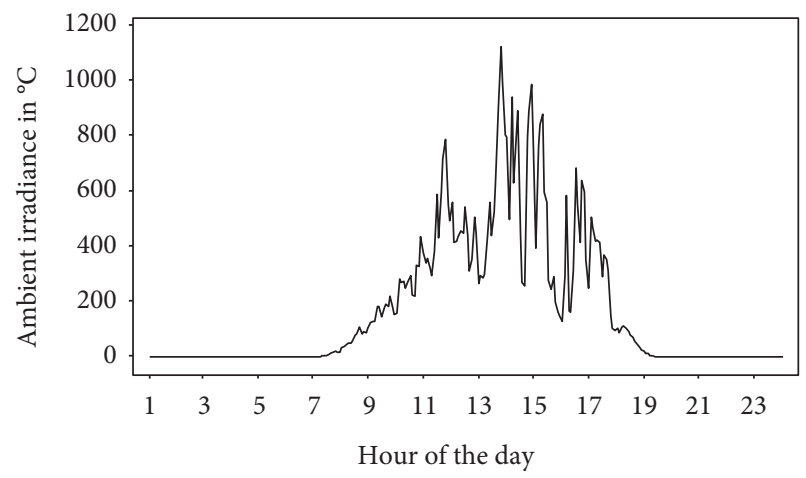

FIGURE 16: A plot of ambient irradiance at the remote seismic node.

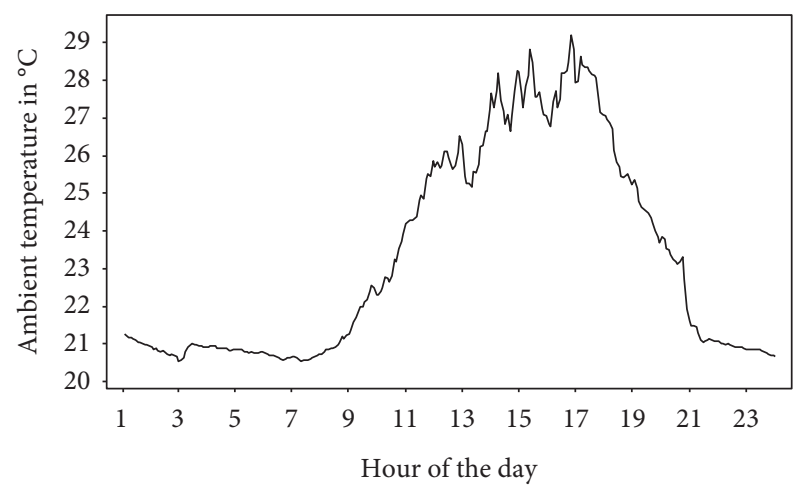

FIgURE 17: A plot of ambient temperature at the remote seismic node.

3.3.6. The Remote Seismic Node PV Module Model. Using Simulink, the model of the solar cell is developed from its mathematical equations. The simulations and the encapsulated model are shown in Figure 22. The considerations were implemented, and ambient irradiance and temperature measurements in Figures 16 and 17 were utilized as inputs for the PV model. The voltage across the node, the generated current, and power measurements were plotted in 
TABLE 3: Observations and computed values at the remote seismic node.

\begin{tabular}{|c|c|c|c|c|c|}
\hline Ambient irradiance $\left(W_{m^{-2}}\right)$ & Ambient temperature $\left({ }^{\circ} \mathrm{C}\right)$ & $I_{\mathrm{pv}}(\mathrm{A})$ At $250 \mathrm{C}$ & $I_{\mathrm{pv}}(\mathrm{A})$ At $1000 W_{m^{-2}}$ & $I_{\text {sat }}(\mathrm{A})$ at $1000 W_{m^{-2}}$ & $I_{\mathrm{sh}}(\mathrm{A})$ \\
\hline 0 & 18.41 & 0 & 3.789 & $3.951 * 10^{-10}$ & 0.3734 \\
\hline 34.81 & 19.03 & 0.1323 & 3.79 & $4.221 * 10^{-10}$ & 0.3732 \\
\hline 96.2 & 20.1 & 0.3656 & 3.792 & $4.73 * 10^{-10}$ & 0.373 \\
\hline 185.2 & 21 & 0.7038 & 3.793 & $5.204 * 10^{-10}$ & 0.37328 \\
\hline 227.4 & 22 & 0.8641 & 3.795 & $5.788 * 10^{-10}$ & 0.37326 \\
\hline 517.9 & 23 & 1.968 & 3.797 & $6.437 * 10^{-10}$ & 0.3734 \\
\hline 719.1 & 25 & 2.733 & 3.8 & $7.96 * 10^{-10}$ & 0.372 \\
\hline 800 & 26 & 3.04 & 3.802 & $8.851 * 10^{-10}$ & 0.3718 \\
\hline 985 & 27 & 3.743 & 3.803 & $9.842 * 10^{-10}$ & 0.3716 \\
\hline 1000 & 35.88 & 3.8 & 3.813 & $2.522 * 10^{-9}$ & 0.3697 \\
\hline
\end{tabular}

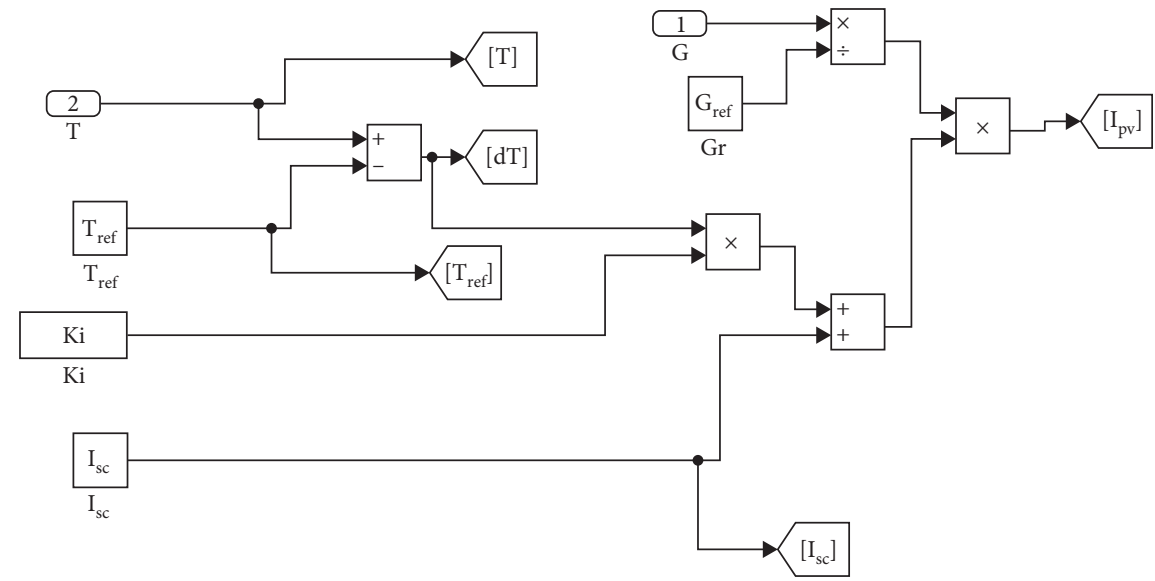

FIgURE 18: Modelled and implemented $I_{\mathrm{PV}}$ at the node.

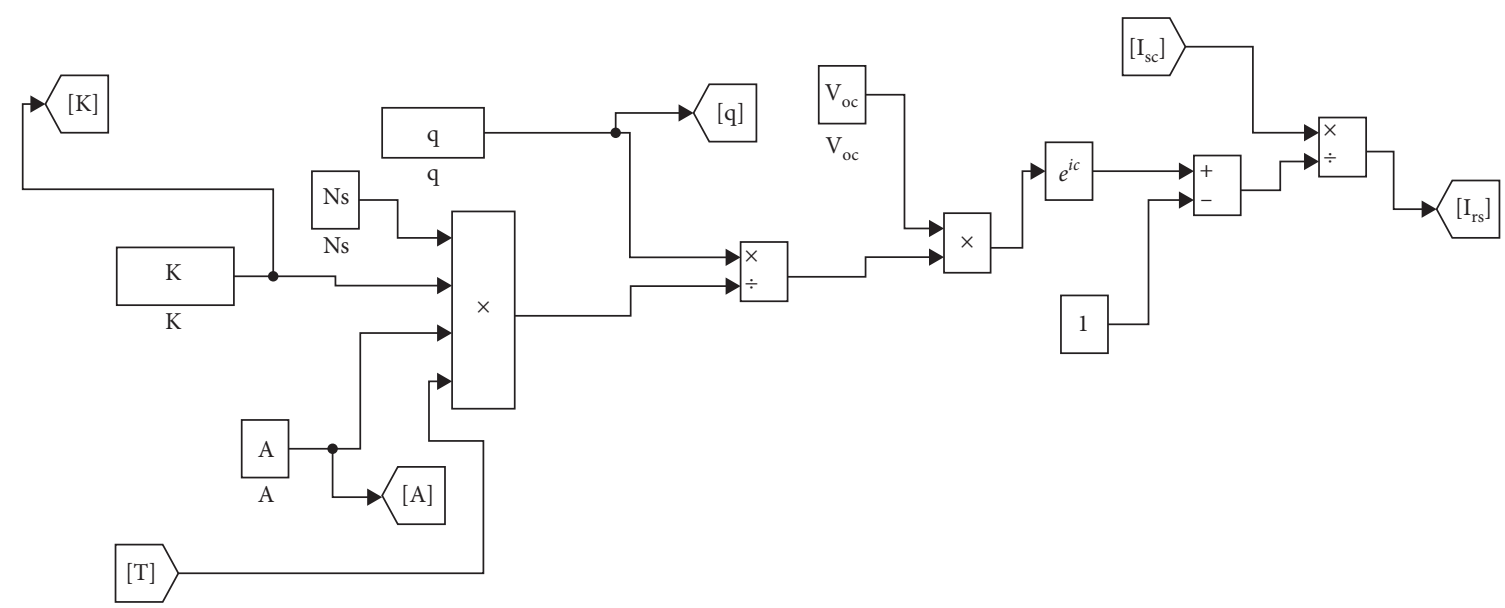

Figure 19: Modelled and Implemented $I_{\mathrm{rs}}$ at the node.

TABle 4: The PV module Specifications.

\begin{tabular}{lc}
\hline Description & Specification \\
\hline PV array & $60 \mathrm{~W} \mathrm{X} 4$ module \\
$V_{\mathrm{oc}}$ & $21.1 \mathrm{~V}$ \\
$V_{\max }$ & $17.1 \mathrm{~V}$ \\
$I_{\mathrm{sc}}$ & $3.8 \mathrm{~A}$ \\
$I_{\max }$ & $3.5 \mathrm{~A}$ \\
\hline
\end{tabular}

Figures 23-25, respectively. It can be revealed that the PV module simulated outputs of the model have good consistency with the theoretically expected results.

3.4. Lead-Acid Battery at the Case Study. At the Nsukka seismic node, a lead-acid battery with $12 \mathrm{~V}$ and $200 \mathrm{Ah}$ 


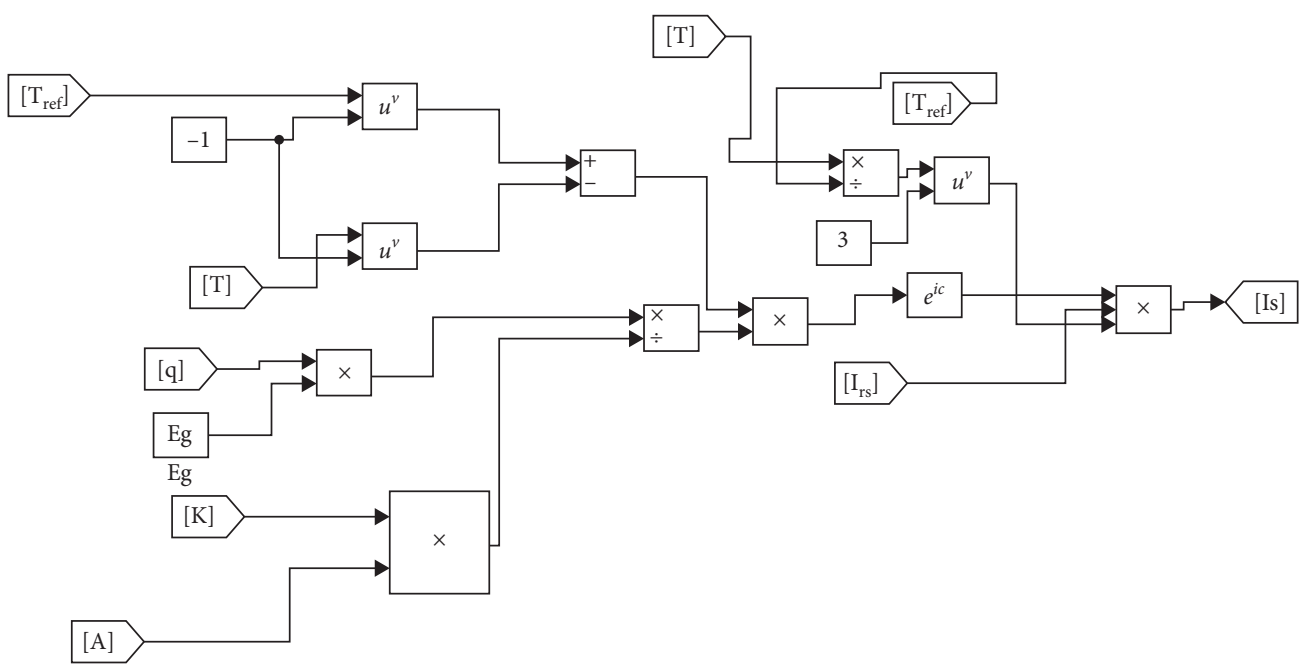

Figure 20: Modelled and implemented $I_{\text {sat }}$ at the node.

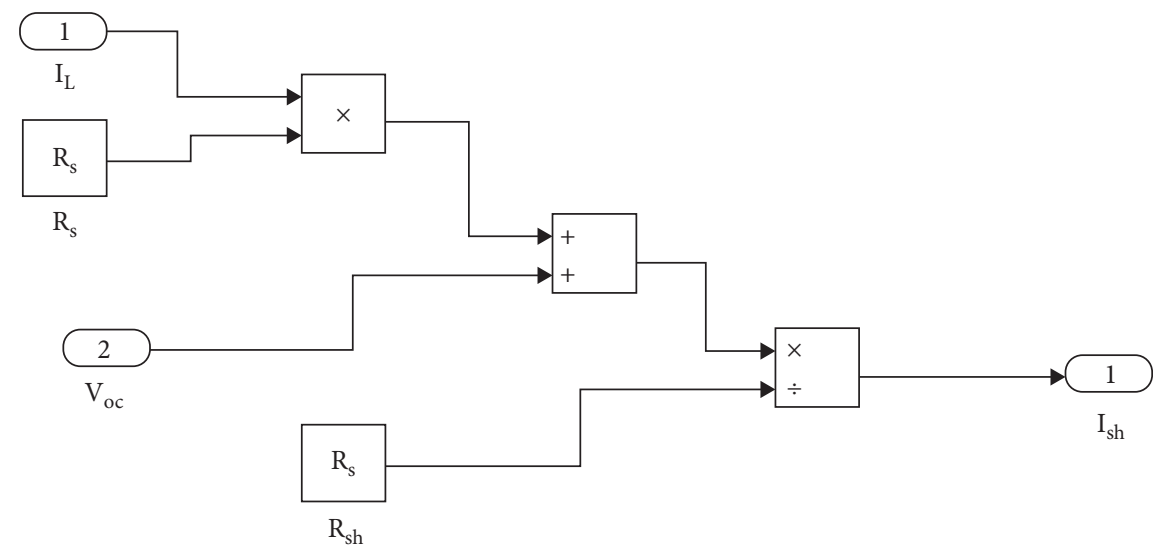

Figure 21: Modelled and implemented $I_{\text {sh }}$ at the node.

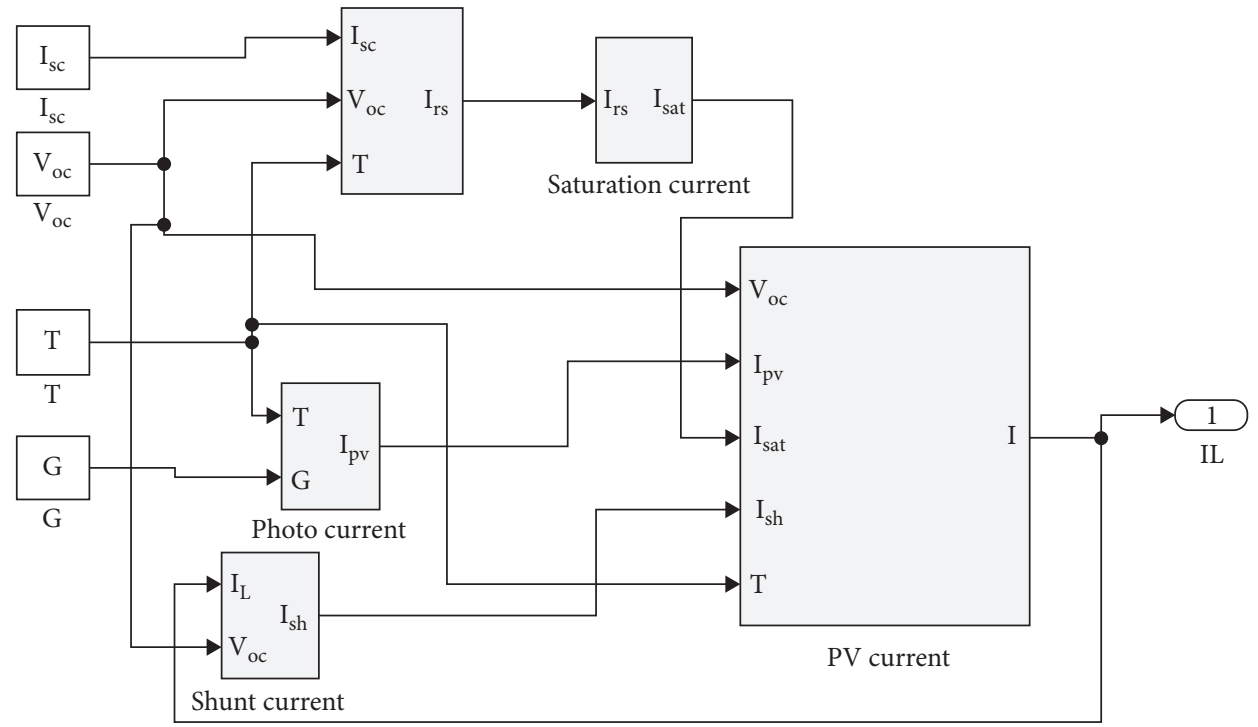

Figure 22: Modelled and implemented PV module node: subsystems topology. 


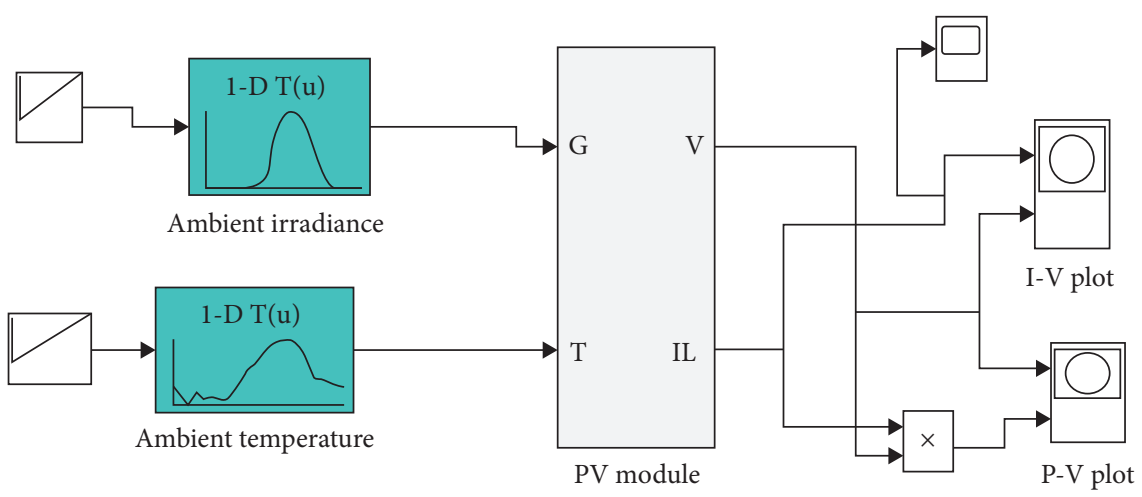

FIGURE 23: Modelled and implemented PV module node: block diagram.
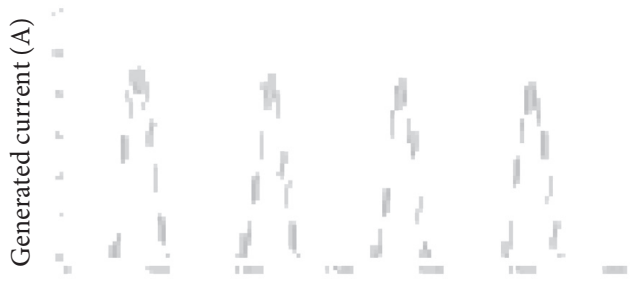

Time

Figure 24: Generated current at the node.

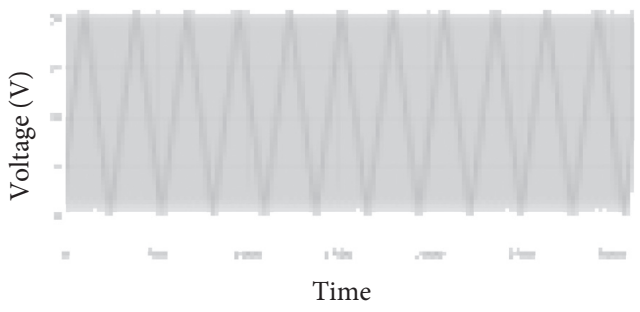

Figure 25: Voltage across the node.

characteristics is installed. It is expected to last for three years or more, and, during this period, it usually underperforms and exhibits irregular voltage levels [48]. Figure 26 shows the simulation plot of the lead-acid battery effects and the output voltage levels in three years at the node. Relating Figures 26 and 27 , during the first year, at the times of the nonavailability of irradiance levels, the voltage levels were above $13.2 \mathrm{~V}$. After a year, the voltage dropped below $12.75 \mathrm{~V}$. This implied that the battery has lost its ability to take charge well and discharges quickly, and lifespan has started to degrade. The slow charging curve of the battery is shown in Figure 28 . Figure 29 shows how it hurriedly discharges when the battery is fully charged. It is important to note that Figure 27 clearly shows how the energy applied to the module and forwarded to the battery is not efficiently utilized. At 14:00 hours during the day, the battery is fully charged, and over $50 \%$ of the ambient irradiance are wasted away due to the inability of the battery to efficiently utilize the available energy provided by the module.

A hybrid of the lead-acid battery and supercapacitor is presented in this study. This is to avoid voltage level drops

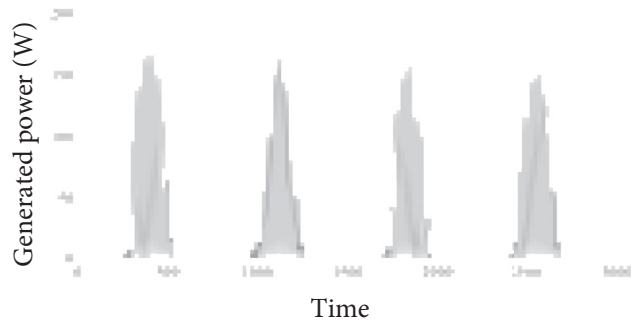

Figure 26: Generated power at the node.

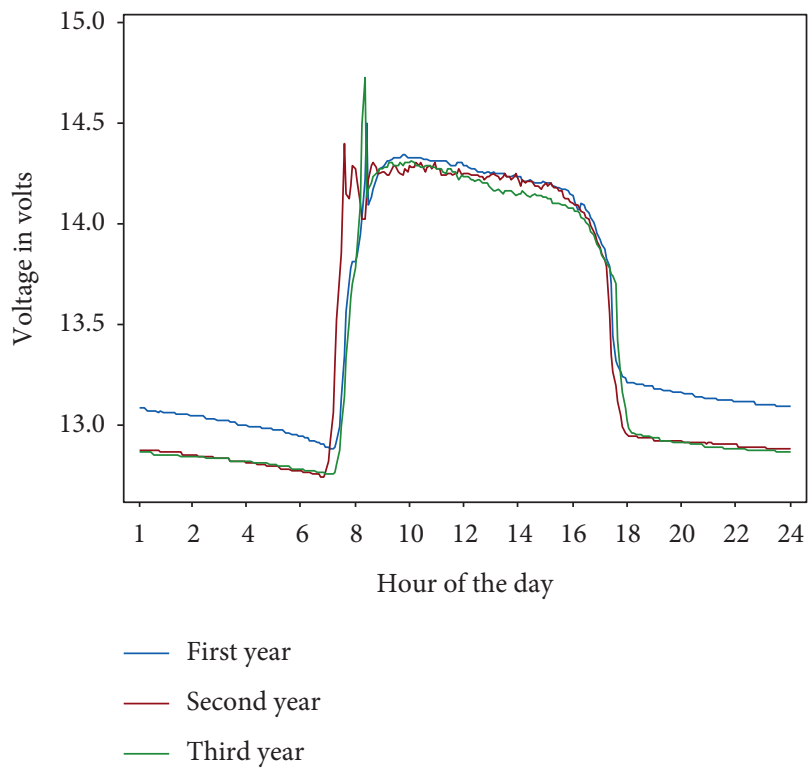

Figure 27: The lead-acid battery voltage for 3-year period.

during the three years of the expiring period of the battery and maximize the available irradiance.

The consideration for the sizing of the PV system consists of sun hours at the node, system losses, the load in Ampere hour ( $\mathrm{Ah}$ ) expected to be consumed in 24 hours, the number of modules, and lead-acid battery specification. Based on Table 2 values, these considerations were sized to meet the requirements of the electrical demand of the remote seismic node. 


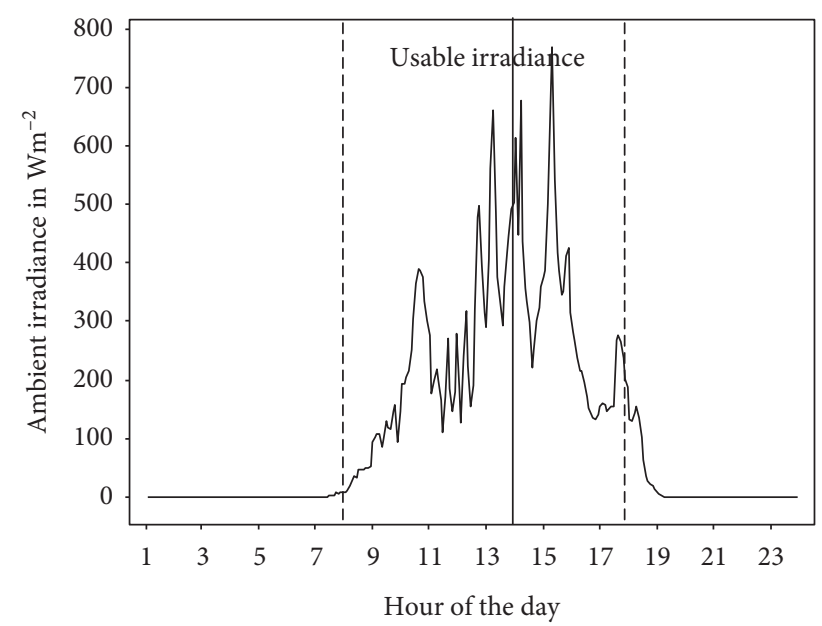

FIGURE 28: Variation of ambient node irradiance at the node.

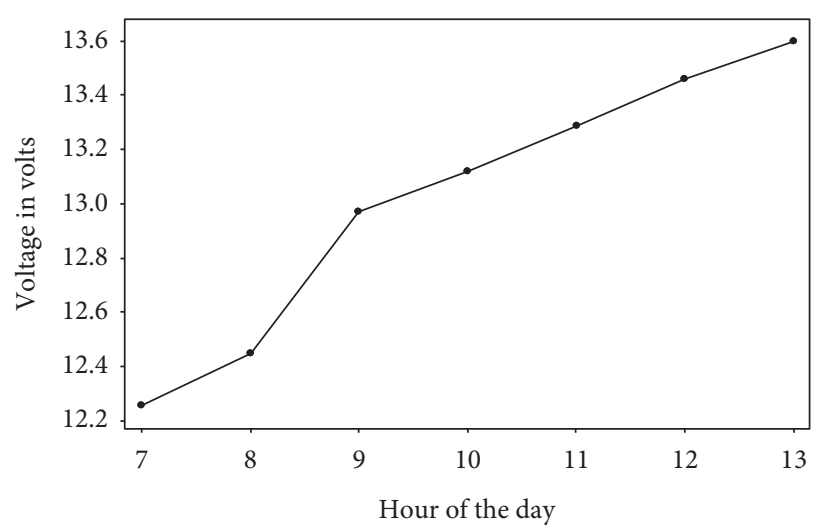

FIgURE 29: A lead-acid battery voltage charging curve.

The average energy consumed per day [49] is expressed as follows:

$$
\begin{aligned}
\frac{\mathrm{Ah}}{\text { day }} & =\frac{\text { power consumed }}{\text { voltage across the load }} * 24 \text { hours } \\
& =\frac{9.6}{12} * 24=19.2 \mathrm{Ah} / \text { day. }
\end{aligned}
$$

For the PV module, the number of the module in parallel is expressed as follows:

$$
\begin{aligned}
& =\operatorname{Ah} / \text { day } * \frac{(1 *(\text { systems losses in } \%)) * \text { ALR }}{((\text { sun hours of the node }) * t(\text { Imax of the module }))} \\
& =19.2 \frac{(1+20 \%) * 1.3}{5 * 3.5}=1.7 \text { modules of } 60 \text { Watts each, }
\end{aligned}
$$

where ALR is array to load ratio.

For the lead-acid battery, the capacity is expressed as

$$
\begin{aligned}
& =\frac{\mathrm{Ah} / \text { day } * \text { battery autonomy }}{\text { maximum battery depth of discharge }} \\
& =\frac{19.2 * 5}{80 \%}=120 \mathrm{Ah} .
\end{aligned}
$$

There are several losses at individual remote seismic nodes triggered by these factors: parameters of the subsystems, mismatch of the subsystems, aging of the subsystems, ambient temperature, air, and soil pollutions. At the Nsukka seismic node, which is a typical African location, the following assumptions were adopted:

(i) Sun hours $=5$

(ii) Battery autonomy $=5$

(iii) Depth of discharge of a lead-acid battery $=80 \%$

(iv) System losses include DC-DC losses and associated peripherals $=20 \%$

3.5. Electrical Power Conditioning. The electrical power conditioning system for a solar harvesting system based MPPT comprises MPPT electronic circuit, power converter, and energy storage, as shown in Figure 30. The system exploits solar energy sources using an algorithm to determine optimal duty cycles for its power converter. Figures 31 and 32 are the PV system circuits for simulating MPPT operations to deliver maximum power levels. The converter requires duty cycles to deliver a fixed voltage at the load and energy storage irrespective of the input voltage levels. Neural 


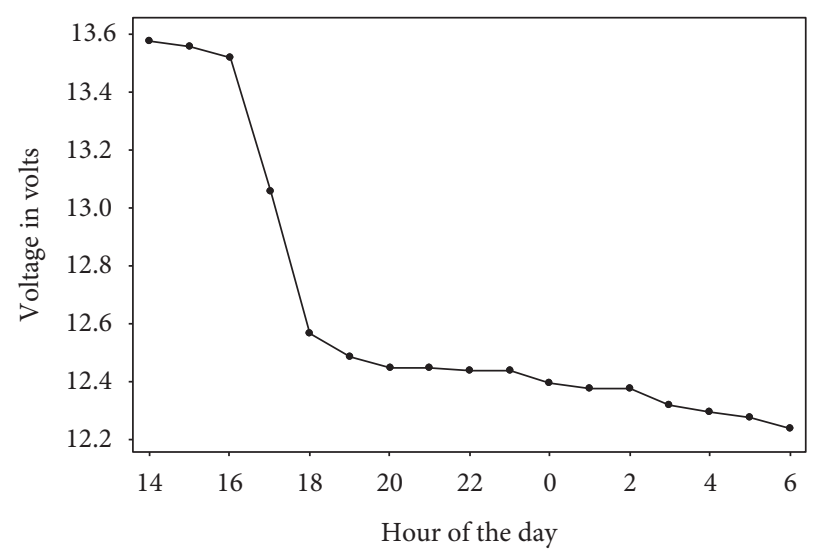

Figure 30: A lead-acid battery voltage discharging curve.

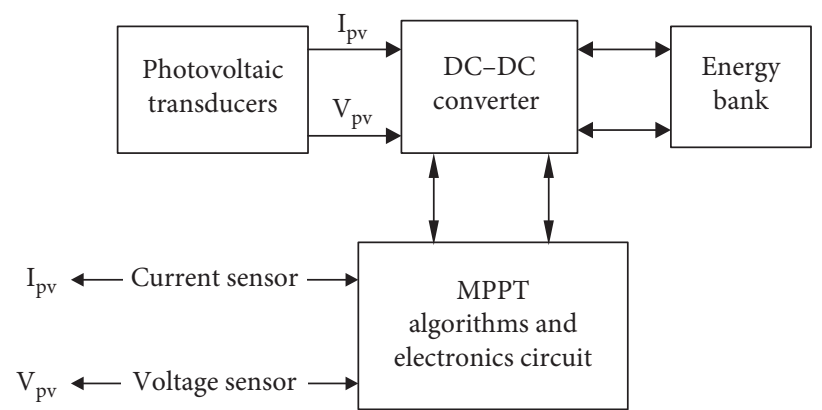

FIgURE 31: Basic energy harvesting system with a conventional MPPT unit.

network-based MPPT is proposed to provide optimal duty cycles across the DC-DC converter. The Perturb and Observe algorithm is only used in this study to acquire historical data using PSIM as the simulating tool. At the same time, the neural network model trains these data and predict duty cycles. The historical data consists of ambient irradiance and temperature levels as the input measurements, and the outputs are duty cycles.

3.6. Proposed Solution Design. The proposed design is presented in Figure 33, consisting of a PV module, DC-DC converters, neural network controller with a hybrid of leadacid battery, and supercapacitor to feed the remote seismic nodes.

3.7. Hybrid of Lead Acid and Supercapacitor. Simulink tool was used for the proposed design, and the parameters in the case study were considered. Figures 34 and 35 are DC-DC buck converters connected to battery only, a hybrid of the battery, and supercapacitor, respectively.

The simulation plots from Figures 36-39 are the simulated results, with the DC-DC converter feeding available energy to both energy storage and the load. Since seismic instrumentations are low power systems with a relatively small budget, a passive connection of the lead-acid battery and supercapacitor is an optimal choice. The overall power capacity is optimized with a passive connection between the energy storage [50].

3.8. Implementation of the Neural Network Algorithm. The neural network model has successfully tackled complex problems in various areas of application, such as learning trend patterns in the time series and predicting accurately within the data and future patterns. The nonuniformity of ambient irradiance and temperature levels throughout the year has made a PV system inefficient and requires prediction [51]. The neural network algorithm delivers accurate predictions from historical data of the system [52]. The procedure of the network is to acquire historical data containing patterns of input and target measurements. In this study, a neural network algorithm is implemented in the solar energy harvesting system to optimally predict duty cycles based on ambient irradiance and temperature levels at the remote seismic node. As shown in Figure 33 stated earlier, the DC-DC converter duty cycles are adjusted using the neural network algorithm and tend to offer simplicity and efficiency.

Perturb and Observe algorithm on the PSIM platform was used to simulate ambient irradiance and temperature levels at Nsukka seismic node to acquire corresponding duty cycle values. The acquired measurements, serving as the historical data for the neural network, were trained and used to carry out predictions on the samples within and outside 


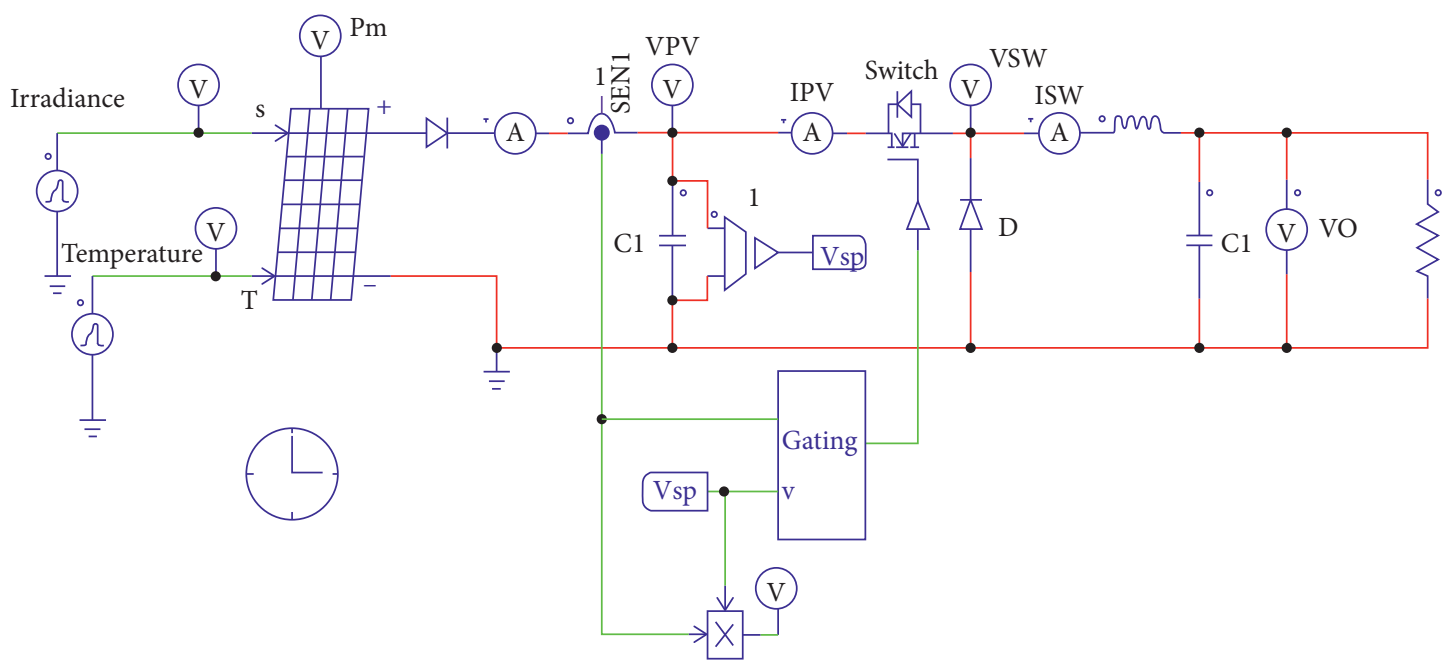

FIgURE 32: PV-based buck converter and MPPT conventional MPPT circuits.

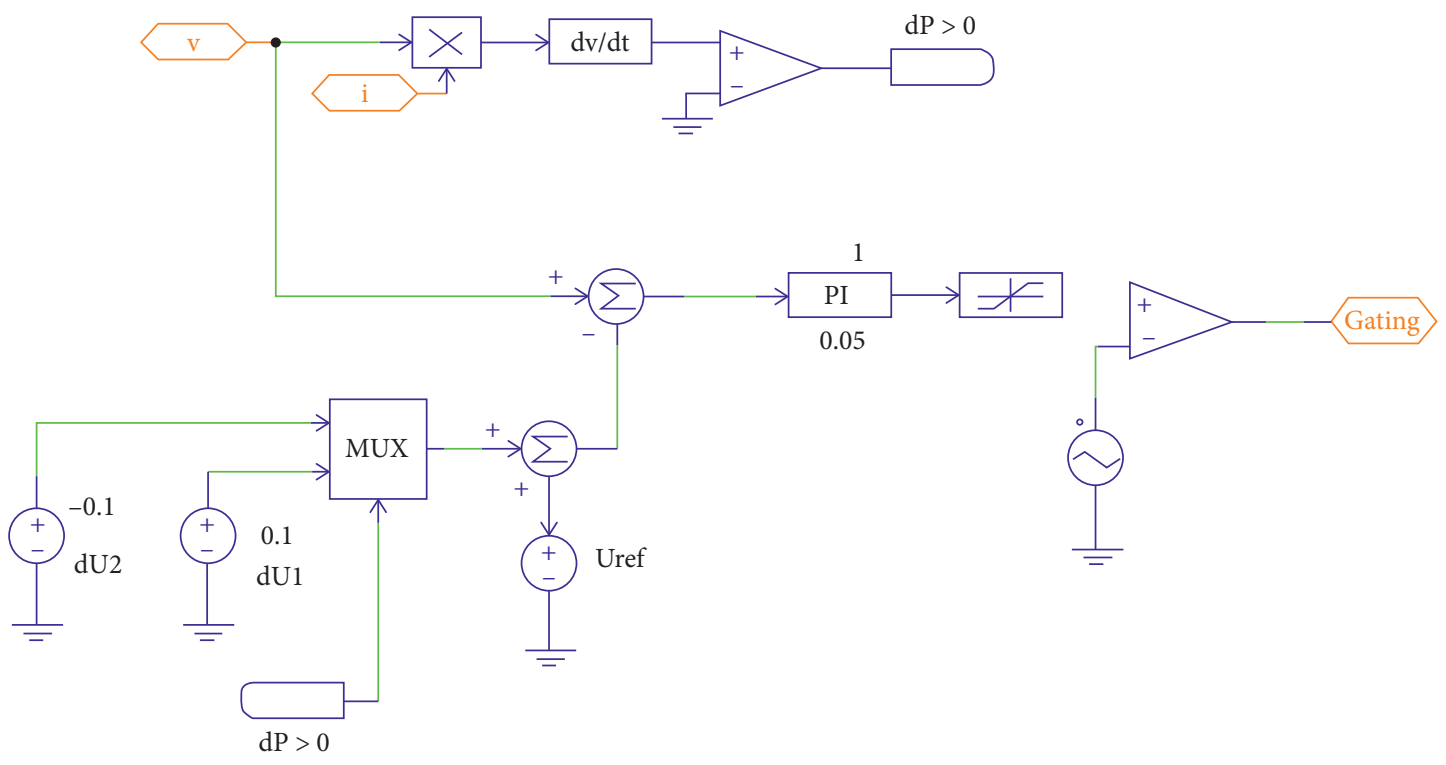

FIgUre 33: Perturb and observe algorithm MPPT circuit.

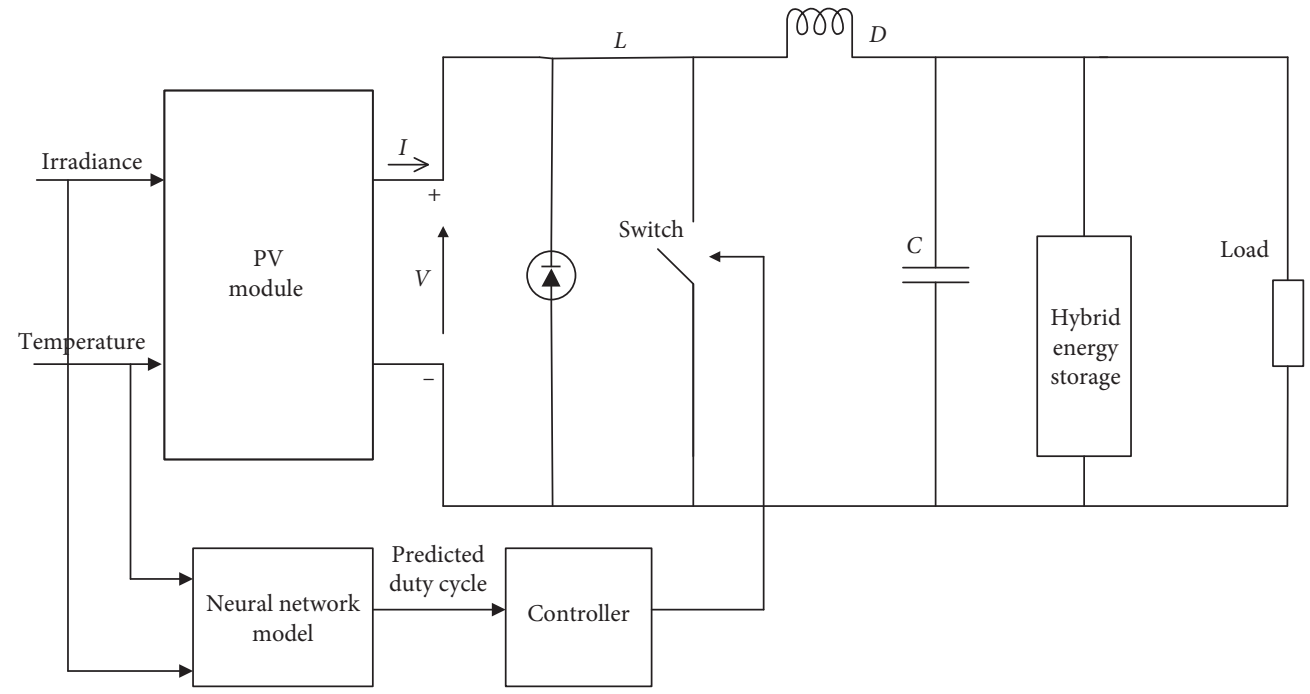

FIgURE 34: Solar Energy Harvesting System with MPPT-based neural network algorithm. 


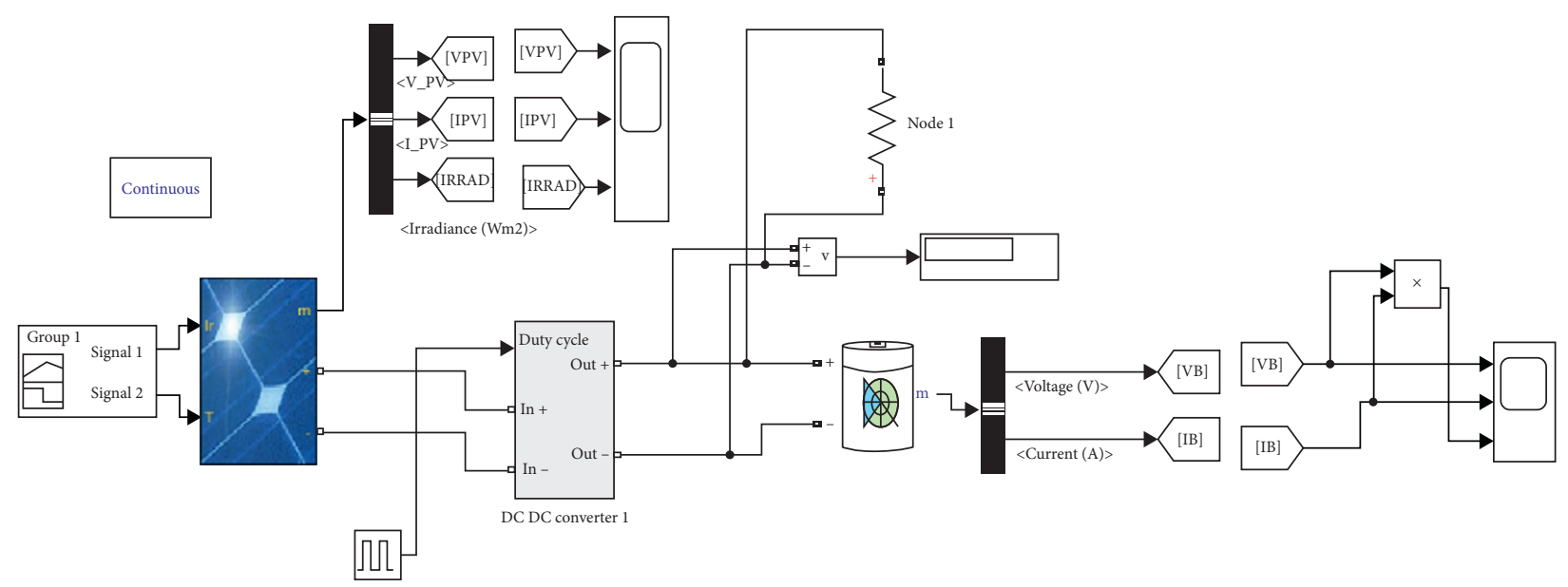

Figure 35: Simulink circuit of lead-acid battery.

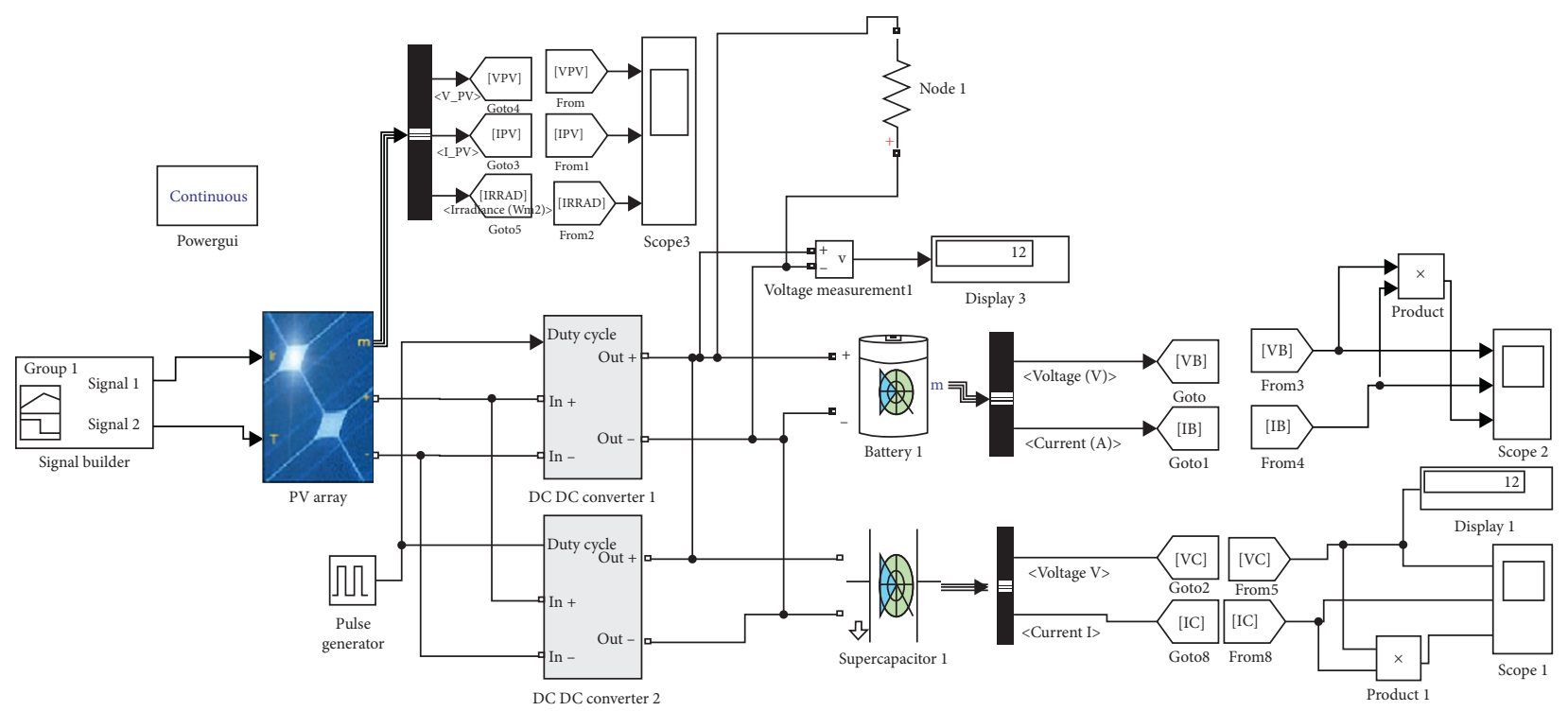

Figure 36: Simulink circuit of hybrid of the lead-acid battery and supercapacitor.

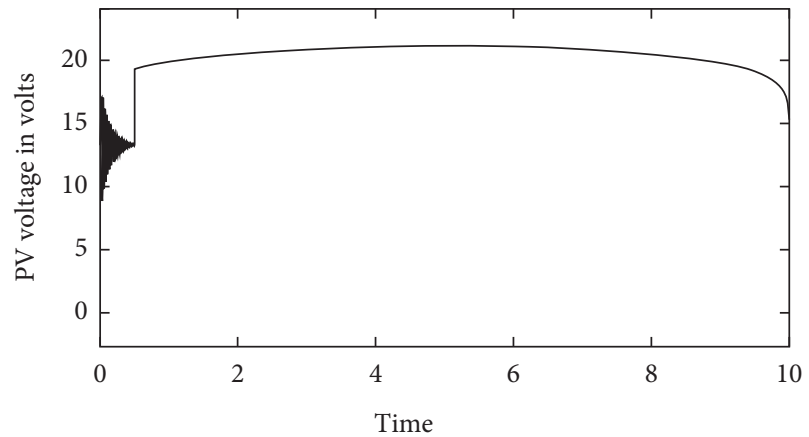

FIgURE 37: PV voltage across the module.

the historical data. Inputs for the training of the historical data contain 2038 samples. The number of neurons controls how the model learns from historical data. Fewer neurons

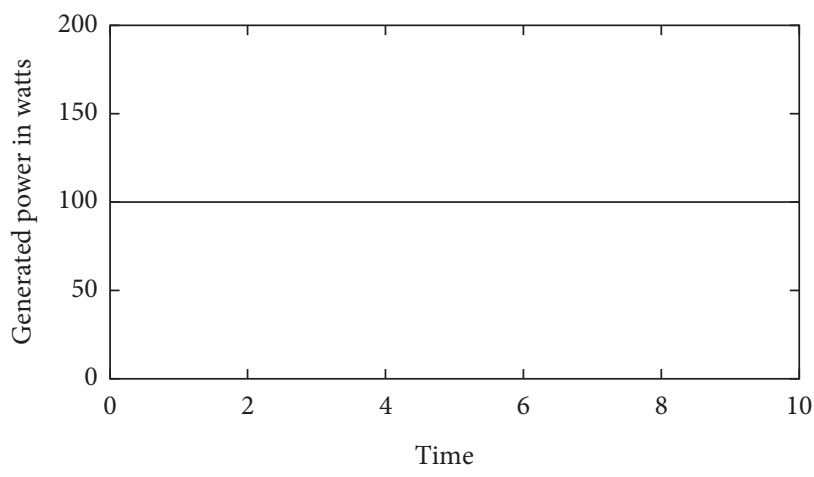

FIGURE 38: Battery only generated power.

underfit the data, and excessive ones overfit it [53]. The optimal number lies between the underfitting and the overfitting. The proposed study selected 11 neurons as the 


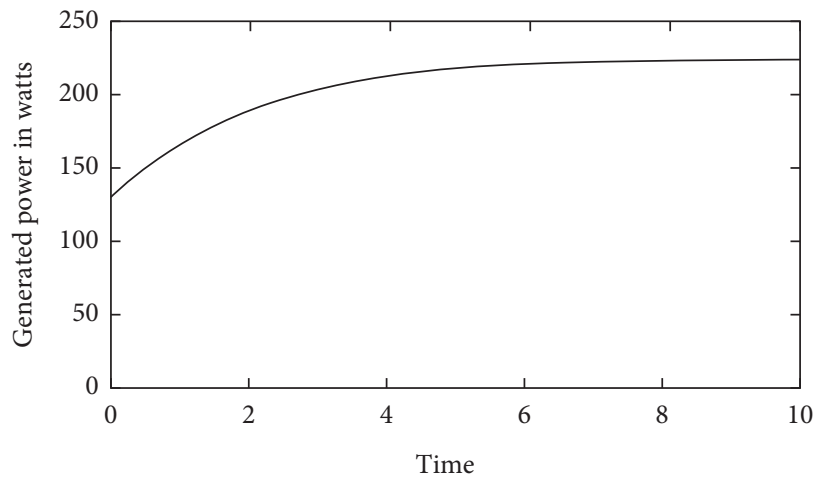

FIgURE 39: Generated power by the hybrid.

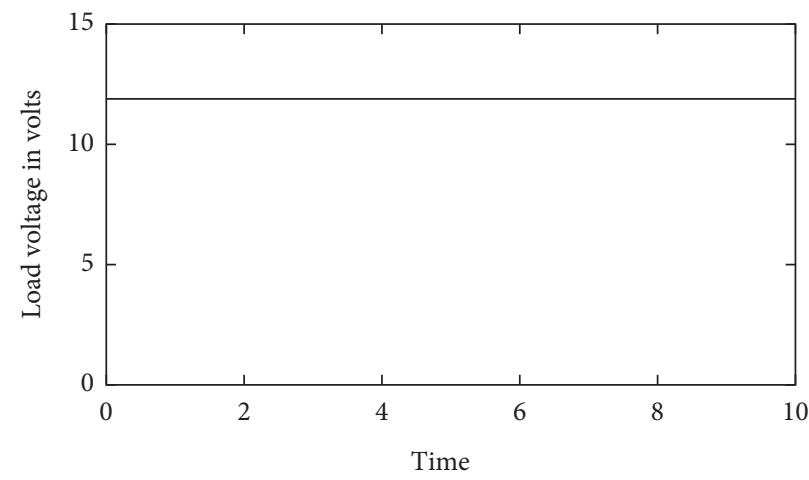

Figure 40: Terminal voltage at the node.

TABLE 5: Verification of the neural network algorithm.

\begin{tabular}{lccccc}
\hline $\begin{array}{l}\text { Ambient irradiance } \\
\left(W_{m^{-2}}\right)\end{array}$ & $\begin{array}{c}\text { Ambient temperature } \\
\left({ }^{\circ} \mathrm{C}\right)\end{array}$ & $\begin{array}{c}\text { Observed duty } \\
\text { cycle }\end{array}$ & Observed $V_{\max }(V)$ & $\begin{array}{c}\text { Predicted duty } \\
\text { cycle }\end{array}$ & \begin{tabular}{c} 
Predicted $V_{\max }(V)$ \\
\hline 54.51738
\end{tabular} \\
54.73272 & 25.17504 & 0.752801 & 15.94047 & 0.7520 & 15.9460 \\
54.94806 & 25.17576 & 0.752800 & 15.94049 & 0.7520 & 15.9457 \\
55.1634 & 25.17648 & 0.752799 & 15.94051 & 0.7520 & 15.9454 \\
345.208 & 25.17720 & 0.752798 & 15.94054 & 0.7520 & 15.9451 \\
347.116 & 25.42702 & 0.752227 & 15.95263 & 0.7512 & 15.9376 \\
349.024 & 25.42804 & 0.752267 & 15.95179 & 0.7513 & 15.9339 \\
629.3632 & 25.42906 & 0.752312 & 15.95082 & 0.7513 & 15.9312 \\
629.3824 & 25.74456 & 0.742146 & 16.16932 & 0.7415 & 16.1687 \\
629.4016 & 25.74642 & 0.742147 & 16.16931 & 0.7415 & 16.1686 \\
\hline
\end{tabular}

optimum number, which linked the input information to hidden layers after numerous adjustment tests of the hidden neuron layer and learning rate, as shown in Figure 40. Therefore, the network architecture is $2-11-1$, with 2 input layer neurons (ambient irradiance and temperature levels), 11 neurons in the hidden layer, and 1 output layer neurons (duty cycle).

The neural network model trained the data and delivered the corresponding duty cycles and $V_{\max }$ measurements. The validations of the training are shown in Table 5, which demonstrates the capability of the model.

\section{Results and Discussion}

As stated earlier, the target is to avoid intermittent oversizing or undersizing the energy harvesting system at the remote seismic node and deliver efficient power. The case study simulations confirmed that ambient irradiance and temperature measurements were not regular and depend on the hour of the day. There are direct relationships among the measurements of current, voltage, and power based on (1)-(8), as well as Figures 8-11. Figures 26-29 results for the lead-acid display indicate that the battery was not optimally 

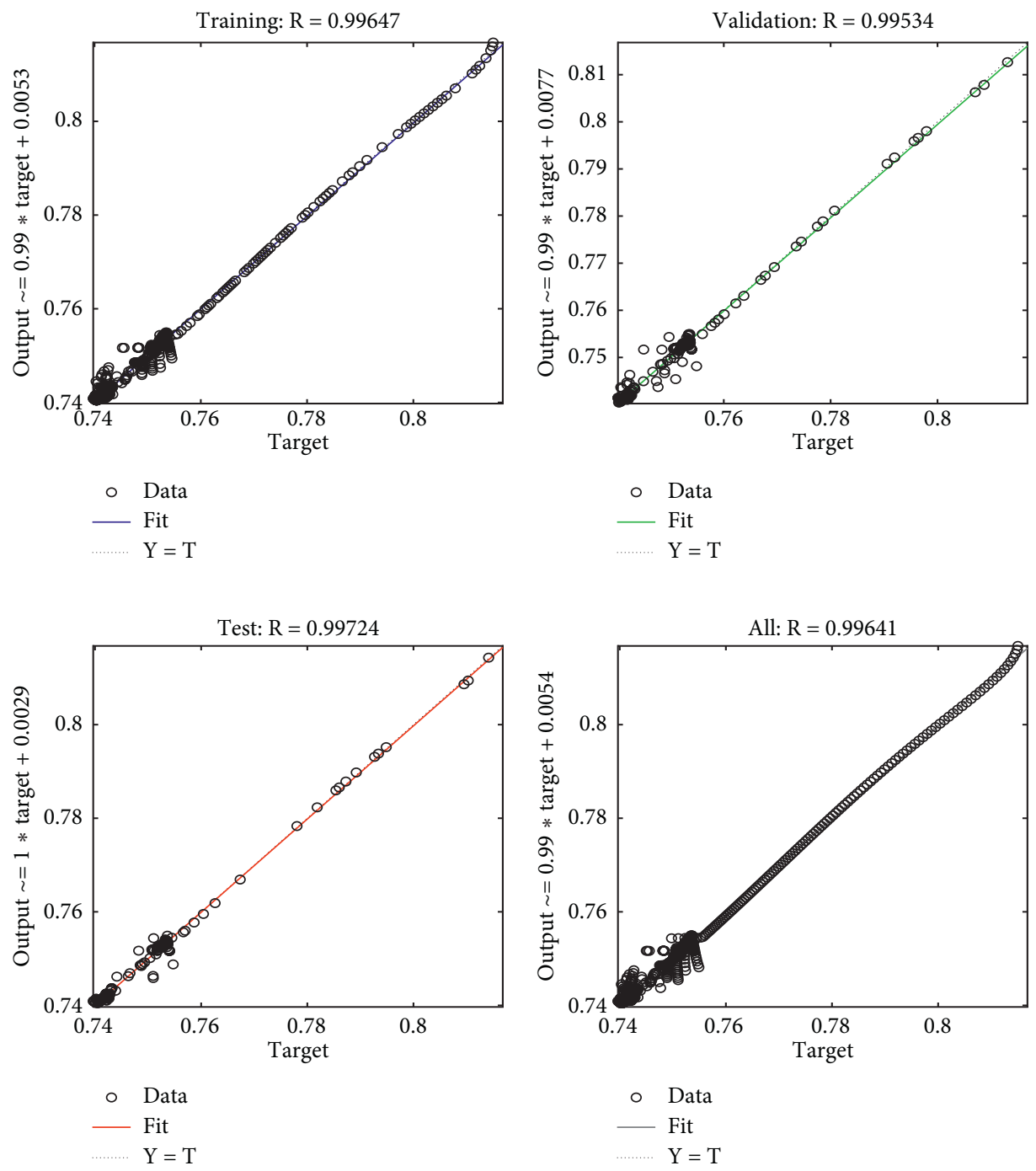

FIGURE 41: The regression results of the trained neural network for training, testing, and validation.

TABLE 6: The remote seismic node electrical specifications.

\begin{tabular}{lc}
\hline Unit & Operating voltage (VDC)/power $(\mathrm{W})$ \\
\hline Seismometer & $12 / 2.4$ \\
Seismic recorder & $12 / 3.6$ \\
GPS & $12 / 1.2$ \\
Mobile router & $12 / 2.4$ \\
\hline
\end{tabular}

utilized and deteriorates relatively faster, and available energy is wasted. Consequently, if the state of charge falls below $50 \%$ and the terminal voltage drops lower than $10 \mathrm{~V}$, the battery performance worsens [54].

Observing Figures 26-29, it is confirmed that almost $50 \%$ of the ambient irradiance is wasted after the battery is fully charged. The hybrid solution of the energy storage enables the supercapacitor to hurriedly feed the node, while the battery supplies during a steady state. Furthermore, the supercapacitor plays a role of optimizing the available energy being wasted and supplies energy when the battery is underperforming. It serves as an energy buffer, as demonstrated in Figures 37 and 38. This saves enough energy and sustains the life of the node on a long-term basis and justifies the cost of the installation. In the case study, the operational PV array was four $60 \mathrm{~W}$ modules and a lead-acid battery of $200 \mathrm{Ah}$. Based on the analysis, it is excessive and unjustified, yet it frequently fails the seismic instrumentation of $10 \mathrm{~W}$.

In this study, DC-DC conversion is taken as one of the considerations to deliver efficient power at the remote seismic node. Since the PV module receives irregular inputs characterized by nonlinearity, the classical MPPT algorithm of the converter delivers output oscillations at the points of tracking maximum power. The neural network model is adopted simply because of its ability to handle nonlinear processes. Figure 41 gives a diagrammatic detail of the proposed design, simulated using the Simulink tool.

The historical data contains 2038 different points utilizing inputs from the case study. The results are shown in Figures 38 and 39. From the results in Figures 38 and 39, it is clear that the $\mathrm{P}$ and $\mathrm{O}$ algorithm was able to deliver 


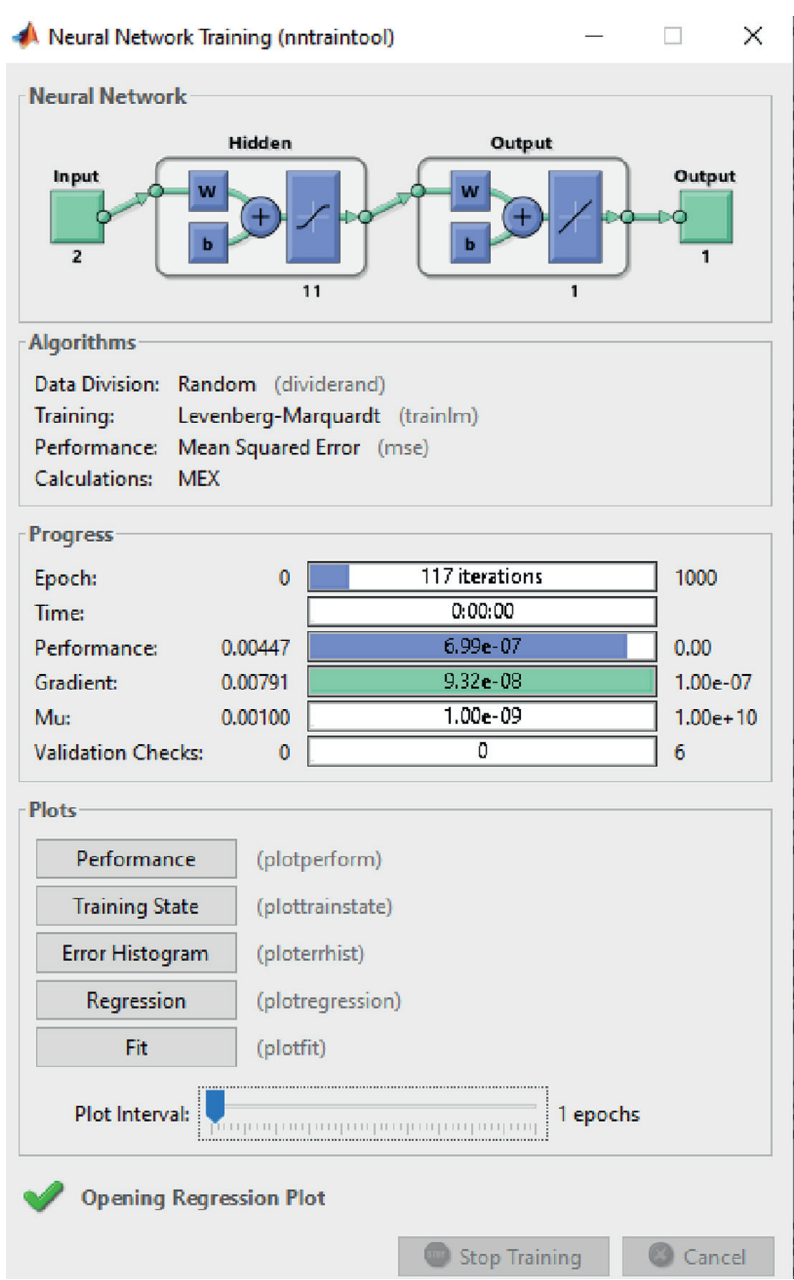

Figure 42: Neural training with NNET tool.

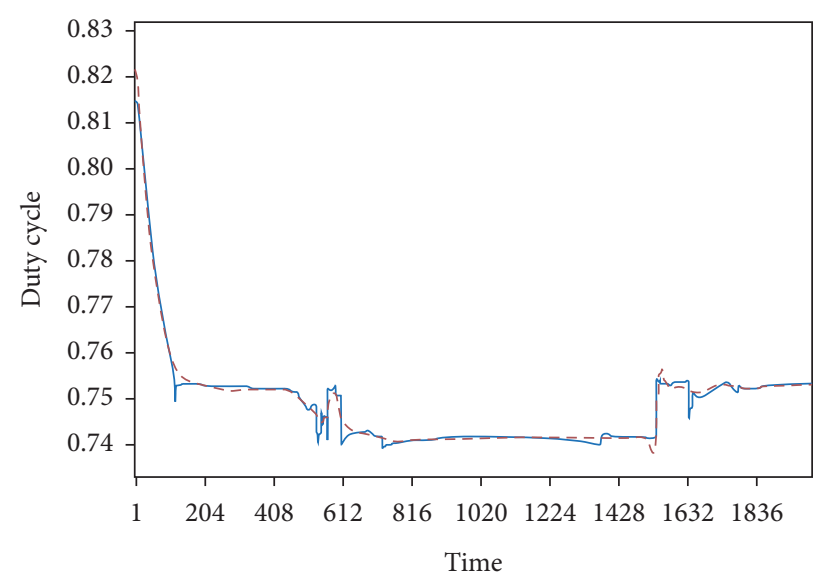

- Observed duty cycle

- - Predicted duty cycle

FIgURE 43: The simulated plot comparing the measured and predicted duty cycles.

consistent historical data for training, validation, and testing. At the same time, the neural network model was able to predict within and outside the historical data to deliver efficient power. Additionally, current and voltage sensors usually incorporated in the usual MPPT controllers are kept away to lower power losses and complexities. 
TABLE 7: Prediction errors in the training.

\begin{tabular}{lcccc}
\hline & Samples & MSE & RMSE & Regression \\
\hline Training & 1426 & $1.33521^{*} 10^{-6}$ & $1.1555^{*} 10^{-3}$ & 0.994179 \\
Validation & 306 & $1.34929^{*} 10^{-6}$ & $1.1615^{*} 10^{-3}$ & 0.990734 \\
Testing & 306 & $1.74384^{*} 10^{-6}$ & $1.3205^{*} 10^{-3}$ & 0.990302 \\
\hline
\end{tabular}

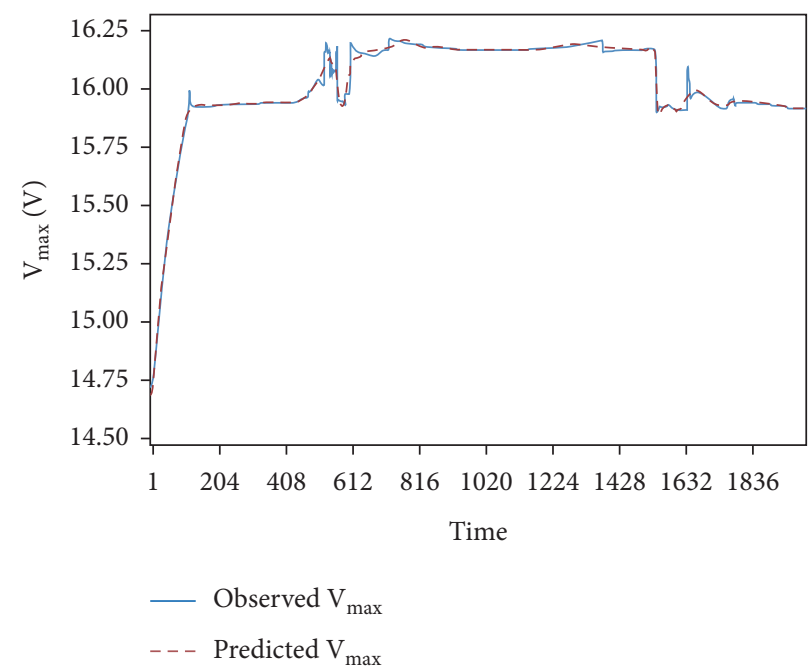

FIGURE 44: The plot simulated comparing the $V_{\max }$ of measured and predicted $V_{\max }$.

TABLE 8: Summary of notations and definitions.

\begin{tabular}{lc}
\hline Notation & Definition \\
\hline$I_{\mathrm{PV}}(\mathrm{G}, \mathrm{T})$ & Photocurrent \\
$G$ & Irradiance \\
$G_{\mathrm{ref}}$ & Reference irradiance \\
$I_{\mathrm{SC}}$ & Short circuit current of the solar cell \\
$d T$ & Difference between the reference and ambient temperature levels \\
$K_{i}$ & Temperature coefficient of $I_{\mathrm{SC}}$ \\
\hline
\end{tabular}

The responses from the proposed design using the neural network model are shown in Tables 6 and 3, as well as Figures 42 and 43 . They demonstrate that the predictions of the neural network model are relatively precise on the inputs measurements within and outside the historical data with no current and voltage sensors.

A smaller mean square error (MSE) implies algorithms of high quality, and the value ranges from 0 to infinity. Models with a smaller mean square error (MSE) value implies a high quality of the algorithms, and the value ranges from 0 to infinity. The errors of the model are presented in Table 3 containing root mean square error (RMSE) and MSE exhibiting the quality of the algorithm. It demonstrates pretty similar measurements, mathematically based on (12) and (13). The table equally shows the regression and tight relationship between the observed and the predicted points:

$$
\begin{aligned}
\text { MSE } & =\frac{\sum_{i=1}^{N}\left(T_{i}-P_{i}\right)^{2}}{N}, \\
\text { RMSE } & =\sqrt{\frac{\sum_{i=1}^{N}\left(T_{i}-P_{i}\right)^{2}}{N} .}
\end{aligned}
$$

$N$ is number of samples, $T$ is outputs, and point is predictions.

Table 7 shows the comparison between the Perturb and Observe MPPT outputs and that of the neural network algorithm. Figure 44 represents a summary of the best validation performance results, indicating that the network was trained until it achieved a very small MSE of 1.1176e- 6 after 117 epochs. Also, the 11 neurons selected for the hidden layer were enabled to deliver an increased regression coefficient $\left(R^{2}\right)$ of 0.9928 (Table 8). 


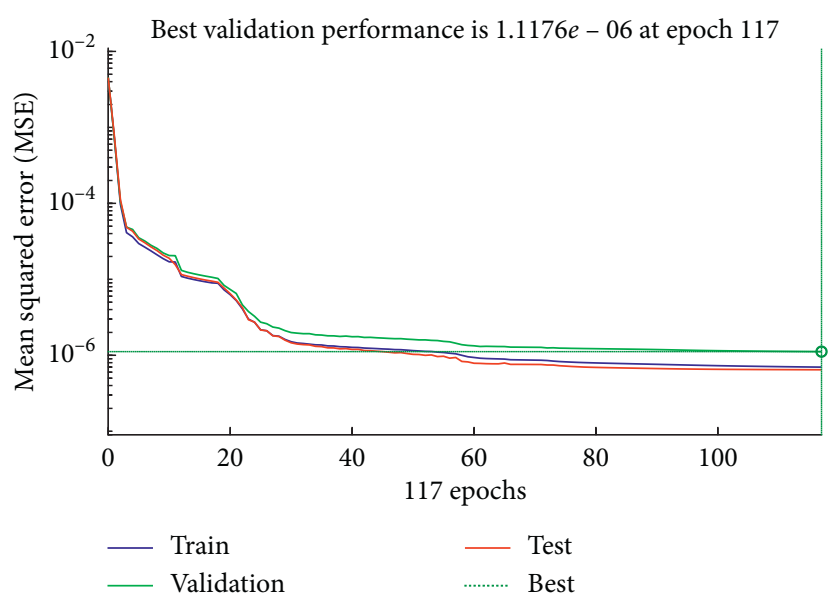

FIgURE 45: The performance curves of the best network prediction.

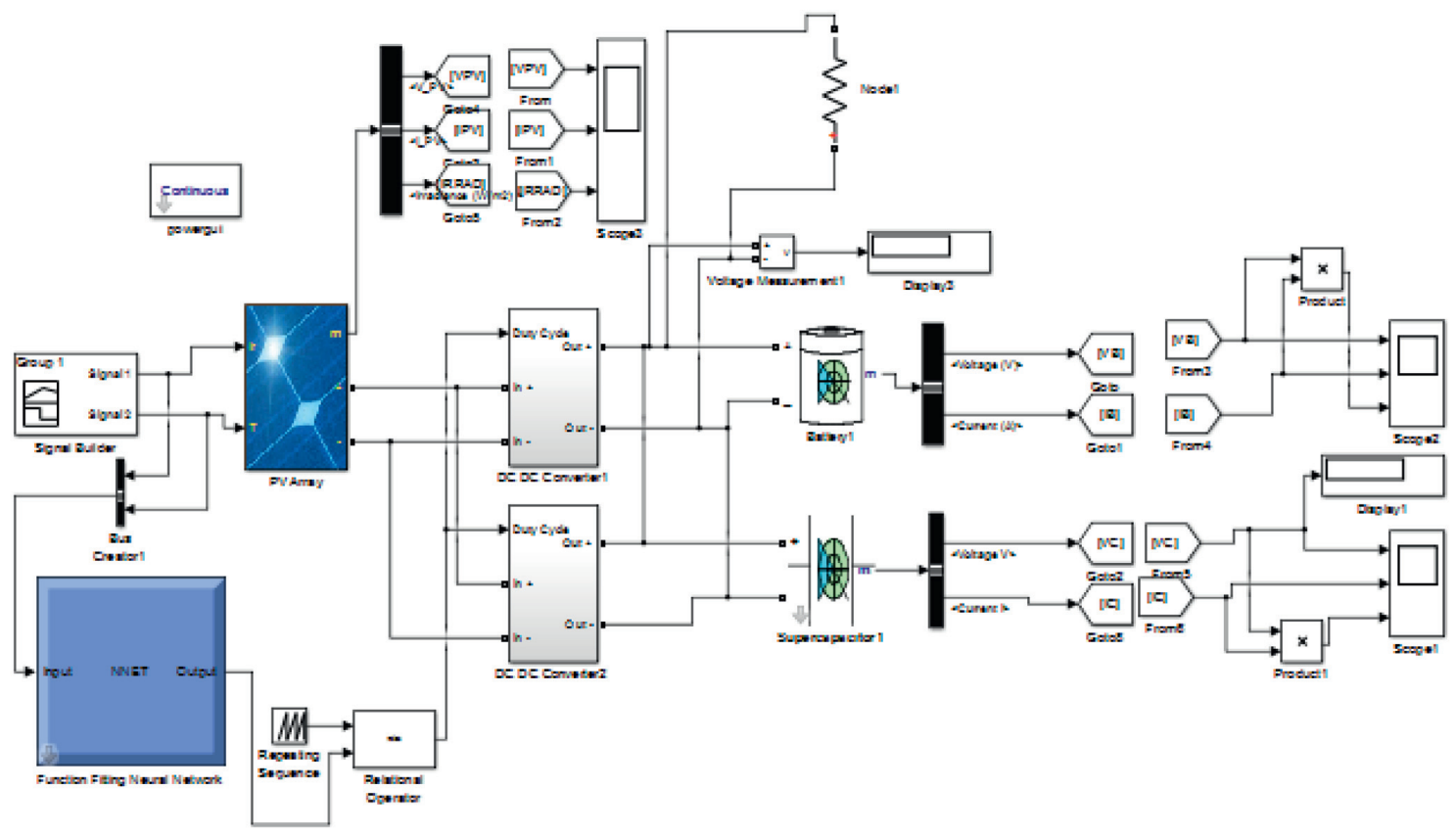

Figure 46: Proposed overall circuit.

Figure 45 represents the regression plot of the model. It can be observed that all the sample points were fitted along the lines, implying the model is accurate and can be used for predicting the outputs.

The proposed overall circuit is shown in Figure 41, consisting of a PV system with neural network-based MPPT, including a hybrid of lead-acid battery and supercapacitor (Figure 46).

\section{Conclusion}

Through simulations, the study has demonstrated that the hybrid of lead-acid battery and supercapacitor energy storage can generate up to $180 \mathrm{~W}$ from the case study parameters at steady-state, with high efficiency. Optimally and conveniently, $50 \%$ of the resources presented at the case study can deliver the power requirements at a remote seismic node and sustain the node on a long-term basis. DCDC converter and neural network design have been proposed in this study, with an efficiency of $75 \%$. The proposed designs have obvious improvements over the usual techniques utilized at the remote seismic nodes by means of simulations. Extracting maximum power from the PV system at a remote seismic node is essential due to low funding for seismic deployments across the globe, which will ensure the long-term and continuous seismic data acquisition for the near real-time prediction of an earthquake to be feasible. 


\section{Data Availability}

The data used in this research were obtained from the belowlisted institution under request ((1) Centre for Atmospheric Research https://carnasrda.com/trodan1/[54]. (2) Centre for Geodesy and Geodynamics, Toro, Nigeria [55], and (3) VLF/ EENTEC (http://www.eentec.com/DR-4050_data.htm [56])).

\section{Conflicts of Interest}

The authors declare that they have no conflicts of interest.

\section{Acknowledgments}

The authors would like to express their sincere acknowledgment to the following: ORDI of the Botswana International University of Science and Technology under Grant R0068 and Centre for Geodesy and Geodynamics, Toro, Nigeria Centre for Atmospheric Research, Anyigba, Nigeria.

\section{References}

[1] C. Vrettos, D. E. Beskos, and T. Triantafyllidis, "Seismic pressures on rigid cantilever walls retaining elastic continuously non-homogeneous soil: an exact solution," Soil $D y$ namics and Earthquake Engineering, vol. 82, pp. 142-153, 2016.

[2] J. Havskov and G. Alguacil, "Seismic sensors," in Instrumentation in Earthquake Seismology, pp. 13-100, Springer, Berlin, Germany, 2016.

[3] L. Ottemoller, J. Havskov, and Seisnet, "SeisNet: a general purpose virtual seismic network," Seismological Research Letters, vol. 70, no. 5, pp. 522-528, 1999.

[4] A. Trnkoczy, P. Bormann, W. Hanka, L. G. Holcomb, and R. L. Nigbor, "Site selection, preparation and installation of seismic stations," in New Manual of Seismological Observatory Practice (NMSOP), pp. 1-108, Deutsches GeoForschungsZentrum GFZ, Potsdam, Germany, 2009.

[5] E. Wielandt, "Seismic sensors and their calibration," in New Manual of Seismological Observatory Practice (NMSOP), pp. 1-46, Deutsches GeoForschungsZentrum GFZ, Potsdam, Germany, 2009.

[6] S. İnan, T. Akgül, C. Seyis et al., "Geochemical monitoring in the marmara region (nw Turkey): a search for precursors of seismic activity," Journal of Geophysical Research: Solid Earth, vol. 113, no. B3, 2008.

[7] W. Jing, C. H. Lai, W. S. H. Wong, and M. L. D. Wong, "A comprehensive study of battery-supercapacitor hybrid energy storage system for standalone pv power system in rural electrification," Applied Energy, vol. 224, pp. 340-356, 2018.

[8] Y. K. Tan and S. K. Panda, "Review of energy harvesting technologies for sustainable wireless sensor network," Sustainable Wireless Sensor Networks, pp. 15-43. In press, 2010.

[9] A. P. Chandrakasan, S. Sheng, and R. W. Brodersen, "Lowpower cmos digital design," IEICE Transactions on Electronics, vol. 75, no. 4, pp. 371-382, 1992.

[10] A. Chandrakasan, R. Amirtharajah, J. Goodman, and W. Rabiner, "Trends in low power digital signal processing," in Proceedings of the 1998 IEEE International Symposium on Circuits and Systems (ISCAS), pp. 604-607, IEEE, Monterey, CA, USA, June 1998.
[11] V. Kyriatzis, N. S. Samaras, P. Stavroulakis, H. Takruri-Rizk, and S. Tzortzios, "Enviromote: a new solar-harvesting platform prototype for wireless sensor networks/work-in-progress report," in Proceedings of the 2007 IEEE 18th International Symposium on Personal, Indoor and Mobile Radio Communications, pp. 1-5, IEEE, Athens, Greece, September 2007.

[12] H. Sharma, A. Haque, and Z. Jaffery, "Modeling and optimisation of a solar energy harvesting system for wireless sensor network nodes," Journal of Sensor and Actuator Networks, vol. 7, no. 3, p. 40, 2018.

[13] S. Suwarno and T. Sutikno, "Implementation of buck-boost converter as low voltage stabilizer at $15 \mathrm{v}$," International Journal of Electrical and Computer Engineering (IJECE), vol. 9, no. 4, pp. 2230-2237, 2019.

[14] A. Pradhan, S. Ali, C. Jena, and P. Behera, "Design and simulation of dc-dc converter used in solar charge controllers," International Journal of Engineering Inventions, vol. 2, no. 3, pp. 59-62, 2013.

[15] M. R. Kumar, S. Ghosh, and S. Das, "Charge-discharge energy efficiency analysis of ultracapacitor with fractional-order dynamics using hybrid optimization and its experimental validation," AEU - International Journal of Electronics and Communications, vol. 78, pp. 274-280, 2017.

[16] R. Szewczyk, J. Polastre, A. Mainwaring, and D. Culler, "Lessons from a sensor network expedition," in European Workshop on Wireless Sensor Networks, pp. 307-322, Springer, Berlin, Germany, 2004.

[17] H. N. Zainudin and S. Mekhilef, "Comparison study of maximum power point tracker techniques for pv systems," in Proceedings of the 14th International Middle East Power Systems Conference, Cairo, Egypt, January 2014.

[18] M. Hlaili and H. Mechergui, "Comparison of different mppt algorithms with a proposed one using a power estimator for grid connected pv systems," International Journal of Photoenergy, vol. 2016, Article ID 1728398, 10 pages, 2016.

[19] M. Elgendy, B. Zahawi, and D. Atkinson, "Evaluation of perturb and observe mppt algorithm implementation techniques," in Proceedings of the 6th IET International Conference on Power Electronics, Machines and Drives (PEMD 2012), Bristol, UK, March 2012.

[20] B. Subudhi and R. Pradhan, "A comparative study on maximum power point tracking techniques for photovoltaic power systems," IEEE Transactions on Sustainable Energy, vol. 4, no. 1, pp. 89-98, 2013.

[21] R. C. Pilawa-Podgurski and D. J. Perreault, "Submodule integrated distributed maximum power point tracking for solar photovoltaic applications," IEEE Transactions on Power Electronics, vol. 28, no. 6, pp. 2957-2967, 2013.

[22] N. Zakzouk, A. Abdelsalam, A. Helal, and B. Williams, "Dclink voltage sensorless control technique for single-phase twostage photovoltaic grid-connected system," in Proceedings of the 2014 IEEE International Energy Conference (ENERGYCON), pp. 58-64, IEEE, Cavtat, Croatia, May 2014.

[23] D. Haifeng and C. Xueyu, "A study on lead acid battery and ultra-capacitor hybrid energy storage system for hybrid city bus," in Proceedings of the 2010 International Conference on Optoelectronics and Image Processing, pp. 154-159, IEEE, Haikou, China, November 2010.

[24] T. Smith, J. Mars, and G. Turner, "Using supercapacitors to improve battery performance," in Proceedings of the 2002 IEEE 33rd Annual IEEE Power Electronics Specialists Conference Proceedings (Cat. No. 02CH37289), pp. 124-128, IEEE, Cairn, Australia, June 2002. 
[25] E. M. Natsheh, A. R. Natsheh, and A. Albarbar, "Intelligent controller for managing power flow within standalone hybrid power systems," IET Science, Measurement \& Technology, vol. 7, no. 4, pp. 191-200, 2013.

[26] L. Elobaid, A. K. Abdelsalam, and E. E. Zakzouk, “Artificial neural network based maximum power point tracking technique for pv systems," in Proceedings of the IECON 201238th Annual Conference on IEEE Industrial Electronics Society, pp. 937-942, IEEE, Montreal, Canada, October 2012.

[27] M. C. Di Piazza, M. Pucci, A. Ragusa, and G. Vitale, "Analytical versus neural real-time simulation of a photovoltaic generator based on a DC-DC converter," IEEE Transactions on Industry Applications, vol. 46, no. 6, pp. 2501-2510, 2010.

[28] M. D. Singh, V. Shine, and V. Janamala, "Application of artificial neural networks in optimizing mppt control for standalone solar pv system," in Proceedings of the 2014 International Conference on Contemporary Computing and Informatics (IC3I), pp. 162-166, IEEE, Mysore, India, November 2014.

[29] I.-S. Cha, J.-G. Choi, G.-J. Yu, M.-W. Jung, H.-L. Baek, and D.-H. Kim, "MPPT for temperature compensation of photovoltaic system with neural networks," in Proceedings of the Conference Record of the Twenty Sixth IEEE Photovoltaic Specialists Conference-1997, pp. 1321-1324, IEEE, Anaheim, CA, USA, October 1997.

[30] T. A. Ocran, J. Cao, B. Cao, and X. Sun, "Artificial neural network maximum power point tracker for solar electric vehicle," Tsinghua Science and Technology, vol. 10, no. 2, pp. 204-208, 2005.

[31] M. C. Di Piazza, M. Pucci, A. Ragusa, and G. Vitale, "A growing neural gas network based mppt technique for multistring pv plants," in Proceedings of the 2010 IEEE International Symposium on Industrial Electronics, pp. 544-549, IEEE, Bari, Italy, July 2010.

[32] V. Raghunathan, A. Kansal, J. Hsu, J. Friedman, and M. Srivastava, "Design considerations for solar energy harvesting wireless embedded systems," in Proceedings of the IPSN 2005. Fourth International Symposium on Information Processing in Sensor Networks, 2005, pp. 457-462, IEEE, Boise, ID, USA, April 2005.

[33] L. Mateu, M. Pollak, and P. Spies, Analog Maximum Power Point Circuit Applied to Thermogenerators, pp. 1-4, iis. fraunhofer. de, Erlangen, Germany, 2008.

[34] R. Simon, M. Kwadiba, J. King, and M. Moidaki, "A history of botswana's seismic network," Botswana Notes and Records, vol. 44, pp. 184-192, 2012.

[35] K. M. Onuoha, "Earthquake hazard prevention and mitigation in the west african sub-region," in Natural and ManMade Hazards, pp. 787-797, Springer, Berlin, Germany, 1988.

[36] J. Shen, S. Dusmez, and A. Khaligh, "Optimization of sizing and battery cycle life in battery/ultracapacitor hybrid energy storage systems for electric vehicle applications," IEEE Transactions on Industrial Informatics, vol. 10, no. 4, pp. 2112-2121, 2014.

[37] C. Krishna, "Managing battery and supercapacitor resources for real-time sporadic workloads," IEEE Embedded Systems Letters, vol. 3, no. 1, pp. 32-36, 2010.

[38] R. A. Dougal, S. Liu, and R. E. White, "Power and life extension of battery-ultracapacitor hybrids," IEEE Transactions on Components and Packaging Technologies, vol. 25, no. 1, pp. 120-131, 2002.

[39] F. Attivissimo, A. Di Nisio, M. Savino, and M. Spadavecchia, "Uncertainty analysis in photovoltaic cell parameter estimation," IEEE Transactions on Instrumentation and Measurement, vol. 61, no. 5, pp. 1334-1342, 2012.

[40] F. Z. Amatoul, M. T. Lamchich, and A. Outzourhit, "Design control of DC/AC converter for a grid connected pv systems with maximum power tracking using matlab/simulink," in Proceedings of the 2011 International Conference on Multimedia Computing and Systems, pp. 1-6, IEEE, Ouarzazate, Morocco, April 2011.

[41] S. Nema, R. Nema, G. Agnihotri et al., "Matlab/simulink based study of photovoltaic cells/modules/array and their experimental verification," International Journal of Energy and Environment, vol. 1, no. 3, pp. 487-500, 2010.

[42] N. Anku, D. Adu-Gyamfi, A. Kankam, A. Takyi, and R. Amponsah, "A model for photovoltaic module optimisation," Journal of Mechanical Engineering and Automation, vol. 5, no. 2, pp. 72-79, 2015.

[43] M. Loulou, M. Al Turkestan, N. Brahmi, and M. Abdelkrim, "Current dependence of series and shunt resistances of solar cells," in Proceedings of the 2018 9th International Renewable Energy Congress (IREC), pp. 1-5, IEEE, Hammamet, Tunisia, March 2018.

[44] M. Y. Suberu, M. W. Mustafa, and N. Bashir, "Energy storage systems for renewable energy power sector integration and mitigation of intermittency," Renewable and Sustainable Energy Reviews, vol. 35, pp. 499-514, 2014.

[45] M. Glavin, P. K. Chan, S. Armstrong, and W. Hurley, "A stand-alone photovoltaic supercapacitor battery hybrid energy storage system," in Proceedings of the 2008 13th International Power Electronics and Motion Control Conference, pp. 1688-1695, IEEE, Poznan, Poland, September 2008.

[46] R. L. Spyker and R. M. Nelms, "Classical equivalent circuit parameters for a double-layer capacitor," IEEE Transactions on Aerospace and Electronic Systems, vol. 36, no. 3, pp. 829$836,2000$.

[47] T. Ma, H. Yang, and L. Lu, "Development of a model to simulate the performance characteristics of crystalline silicon photovoltaic modules/strings/arrays," Solar Energy, vol. 100, pp. 31-41, 2014.

[48] C. Kagiri and X. Xia, "Optimal control of a hybrid battery/ supercapacitor storage for neighborhood electric vehicles," Energy Procedia, vol. 105, pp. 2145-2150, 2017.

[49] A. M. Zungeru, J. M. Chuma, D. Duncan et al., "Design of photovoltaic system for iot devices," in Green Internet of Things Sensor Networks, pp. 55-81, Springer, Berlin, Germany, 2020.

[50] Y. Chuan, C. Mi, and M. Zhang, "Comparative study of a passive hybrid energy storage system using lithium ion battery and ultracapacitor," World Electric Vehicle Journal, vol. 5, no. 1, pp. 83-90, 2012.

[51] Z. Boussaada, O. Curea, A. Remaci, H. Camblong, and N. Mrabet Bellaaj, "A nonlinear autoregressive exogenous (narx) neural network model for the prediction of the daily direct solar radiation,” Energies, vol. 11, no. 3, p. 620, 2018.

[52] P. Dawan, K. Sriprapha, S. Kittisontirak et al., "Comparison of power output forecasting on the photovoltaic system using adaptive neuro-fuzzy inference systems and particle swarm optimization-artificial neural network model," Energies, vol. 13 , no. 2 , p. $351,2020$.

[53] K. G. Sheela and S. N. Deepa, "Review on methods to fix number of hidden neurons in neural networks," Mathematical Problems in Engineering, vol. 2013, Article ID 425740, 11 pages, 2013.

[54] M. Lencwe, S. Chowdhury, and T. Olwal, "A multi-stage approach to a hybrid lead acid battery and supercapacitor system for transport vehicles," Energies, vol. 11, no. 11, p. 2888, 2018. 